\title{
GOME-2 observations of oxygenated VOCs: what can we learn from the ratio glyoxal to formaldehyde on a global scale?
}

\author{
M. Vrekoussis ${ }^{1,3}$, F. Wittrock ${ }^{1}$, A. Richter ${ }^{1}$, and J. P. Burrows ${ }^{1,2}$ \\ ${ }^{1}$ Institute of Environmental Physics and Remote Sensing, IUP, University of Bremen, NW1, P.O. Box 3304 40, 28334, \\ Bremen, Germany \\ ${ }^{2}$ Centre for Ecology and Hydrology, Maclean Building, Benson Lane, Crowmarsh Gifford, Wallingford, Oxfordshire, \\ OX10 8BB, UK \\ ${ }^{3}$ Research Centre for Atmospheric Physics and Climatology, Academy of Athens, 24 Omirou str., Athens, 10672 Greece
}

Received: 29 July 2010 - Published in Atmos. Chem. Phys. Discuss.: 11 August 2010

Revised: 20 October 2010 - Accepted: 21 October 2010 - Published: 1 November 2010

\begin{abstract}
Collocated data sets of glyoxal (CHO.CHO) and formaldehyde (HCHO) were retrieved for the first time from measurements of the Global Ozone Monitoring Experiment2 (GOME-2) during the first two years of operation in 2007 and 2008. Both oxygenated Volatile Organic Compounds, OVOC, are key intermediate species produced during the oxidation of precursor hydrocarbons. Their short lifetime of a few hours in the lower troposphere links them to emission sources and makes them useful tracers of photochemical activity. The global composite maps of GOME-2 HCHO and CHO.CHO have strong similarities confirming their common atmospheric and/or surface sources. The highest column amounts of these OVOCs are recorded over regions with enhance biogenic emissions (e.g. tropical forests in South America, Africa and Indonesia). Enhanced OVOC values are also present over areas of anthropogenic activity and biomass burning (e.g. over China, N. America, Europe and Australia). The ratio of $\mathrm{CHO}$.CHO to $\mathrm{HCHO}, R_{\mathrm{GF}}$, has been used, for the first time on a global scale, to classify the sources according to biogenic and/or anthropogenic emissions of the precursors; $R_{\mathrm{GF}}$ between 0.040 to 0.060 point to the existence of biogenic emissions with the highest values being observed at the highest Enhanced Vegetation Index, EVI. $R_{\mathrm{GF}} \mathrm{S}$ below 0.040 are indicative of anthropogenic emissions and associated with high levels of $\mathrm{NO}_{2}$. This decreasing tendency of $R_{\mathrm{GF}}$ with increasing $\mathrm{NO}_{2}$ is also observed when analyzing data for individual large cities, indicating that it is a common feature. The results obtained for $R_{\mathrm{GF}}$ from GOME-2 data are compared with the findings based on regional SCIAMACHY observations showing good agreement. This is ex-
\end{abstract}

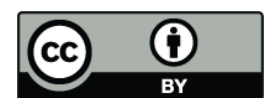

Correspondence to: $\mathrm{M}$. Vrekoussis (vrekoussis@iup.physik.uni-bremen.de) plained by the excellent correlation of the global retrieved column amounts of CHO.CHO and HCHO from the GOME2 and SCIAMACHY instruments for the period 2007-2008.

\section{Introduction}

Volatile Organic Compounds (VOCs) emissions from biogenic, anthropogenic, and biomass burning sources induce significant changes to atmospheric composition. VOCs affect the formation of tropospheric ozone (Houwelling et al., 1998; Poisson et al., 2000), determine the oxidizing capacity of the atmosphere (Vrekoussis et al., 2004, 2006, 2007; Monks et al., 2005; Liakakou et al., 2007), contribute to the formation of secondary organic aerosols, SOA, (Kanakidou et al., 2005; Volkamer et al., 2006) and also to cloud condensation nuclei, CCN, production (Roberts et al., 2002). In order to assess the significance of VOCs in controlling atmospheric chemistry it is important to improve our knowledge of the spatial distribution of their sources and their atmospheric removal. Considering the fact that a large number of different VOC species are emitted to the Earth's atmosphere, smaller molecules which are produced from the oxidation of VOCs, such as formaldehyde (HCHO) and glyoxal (CHO.CHO) are valuable tracers of the VOC sources.

Formaldehyde (HCHO) is a high yield key intermediate reaction product of the VOC oxidation scheme. It is the smallest and most abundant aldehyde member of the family of oxygenated volatile organic compounds family (OVOCs) being produced during the photochemical degradation of methane $\left(\mathrm{CH}_{4}\right)$ and non methane (NMHC) hydrocarbons. Methane oxidation is considered to provide a global HCHO source (Lowe and Schmidt, 1983; Singh et al., 2001;

Published by Copernicus Publications on behalf of the European Geosciences Union. 
Heikes et al., 2001; Frost et al., 2002). The surface levels of $\mathrm{HCHO}$ in the remote marine atmosphere range between 0.3 and $1.0 \mathrm{ppbv}$ (Weller et al., 2000; Singh et al., 2004). In the continental boundary layer, the observed variability of $\mathrm{HCHO}$, superimposed on its global source results from the oxidation of short lived biogenic and anthropogenic NMHCs (Fried et al., 2003). A major precursor of HCHO in such regions is isoprene whose emission comprises more than $40 \%$ of the total VOC surface flux on a global scale. Its global emissions are estimated to be about $500 \mathrm{Tg} \mathrm{yr}^{-1}$ (Guenther et al., 2006), a number exceeding by far the estimates for the anthropogenic sources (Williams, 2004). In addition to the hydrocarbons oxidation, $\mathrm{HCHO}$ also has known primary sources from direct emissions of biomass burning (Lee et al., 1997; Holzinger et al., 1999; Yokelson et al., 1999; Andreae and Merlet, 1999), industrial processes and fuel combustion (Anderson et al., 1994; Geiger et al., 2002) and vegetation (Seco et al., 2006 and references therein). Recently HCHO has also been identified in shipping emissions observed from space (Marbach et al., 2009). Despite its local and/or regional importance, the contribution of the primary sources, on a global scale, is considered to be small or negligible in comparison to the large secondary sources mentioned before. The main sink pathways of HCHO are its photolysis, the oxidation by the hydroxyl radical (Stavrakou et al., 2009a), wet and dry deposition and multiphase chemistry. The lifetime of $\mathrm{HCHO}$ is in the range of a few hours (Arlander et al., 1995; De Smedt et al., 2008). As the lifetime of methane is on the scale of years, the changes of the mixing ratio of $\mathrm{HCHO}$ can be attributed mainly to the oxidation of the NMHCs. This in addition to the short lifetime of HCHO makes the role of transport less significant and enables us to identify photochemical hot spots above the respective sources. However, depending on the ambient conditions, the role of transport may be enhanced. Palmer et al. (2003) concluded that isoprene emissions are related to $\mathrm{HCHO}$ columns on length scales of $10-100 \mathrm{~km}$, a number which exceeds the footprint of GOME-2. This spatial smearing could be even larger when for example the lifetime of the $\mathrm{HCHO}$ precursors is increased during winter.

Glyoxal, CHO.CHO, is the smallest and one of the most prevalent dicarbonyl compounds of the atmosphere. Unlike for $\mathrm{HCHO}$, our knowledge concerning the primary sources of CHO.CHO is very limited (Kean et al., 2001; Grosjean et al., 2001; Hays et al., 2002). CHO.CHO is produced from the oxidation of precursor hydrocarbons having two or more carbon atoms (Calvert at el., 2002). Modeling studies (Fu et al., 2008; Myriokefalitakis et al., 2008) pointed out that the major source of CHO.CHO comes from the oxidation of biogenic VOCs such as isoprenes and terpenes followed by anthropogenic VOCs such as acetylene, benzene, toluene and xylene. A detailed analysis of the sources of CHO.CHO is described in Fu et al. (2008) and Vrekoussis et al. (2009 and references therein). However the attribution of the sources of CHO.CHO is still under investigation. A recent study by Stavrakou et al. (2009b) suggested that the underestimation of the model values in comparison to the satellite glyoxal columns (Wittrock et al., 2006; Vrekoussis et al., 2009) might result from a missing secondary source of CHO.CHO accounting for about $50 \%$ of the global $\mathrm{CHO}$. CHO budget. $\mathrm{CHO}$.CHO is destroyed in the troposphere primarily by photolysis (Fu et al., 2008; Myriokefalitakis et al., 2008). Other sinks are the reaction with $\mathrm{OH}$ radicals and to a lesser extent wet and dry deposition (Myriokefalitakis et al., 2008). As a result of its high solubility, CHO.CHO facilitates the formation of SOA which might explain a significant fraction of the SOA missing in model simulations in the lower and free troposphere (Volkamer et al., 2006, 2007; Fu et al., 2009). However the role of SOA as a source of CHO.CHO is currently uncertain as two independent research studies carried out by Liggio et al. (2005) and Kroll et al. (2005) found that the uptake of CHO.CHO could be irreversible or reversible, respectively. SOA may also serve as an independent glyoxal source via the oxidation or volatilization of other compounds (Kwan et al., 2006). As CHO.CHO is a short-lived species, satellite measurements of its amounts can be used to pinpoint photochemical hot spots (Vrekoussis et al., 2009; Sayer et al., 2010).

The aim of this study is to identify and classify biogenic and anthropogenic emissions on a global scale according to the range of the ratio, $R_{\mathrm{GF}}$, defined as the observed column amounts of CHO.CHO divided by the respective formaldehyde columns. For this purpose the simultaneous global observations of the monthly mean vertical column densities, $\mathrm{VCD}$, of HCHO and CHO.CHO were retrieved for the first time from the measurements of the GOME-2 satellite instrument. Global GOME-2 nitrogen dioxide, $\mathrm{NO}_{2}$, observations and the Enhanced Vegetation Index, EVI (Huete et al., 2002), were used as proxies of the anthropogenic and the biogenic emissions respectively. In addition, a brief comparison of the GOME-2 VOCs results with the ones obtained by the SCIAMACHY satellite instrument (Wittrock, 2006; Wittrock et al., 2006; Vrekoussis et al., 2009) is presented.

\section{The GOME-2 instrument}

The Global Ozone Monitoring Experiment-2 instrument, GOME-2, on board the MetopA satellite was launched in October 2006 into sun synchronous orbit with an equator crossing time of 09:30 LT. GOME-2 is an enhanced version of GOME-1 (Burrows et al., 1999) but has less modes of observation and wavelength coverage than SCIAMACHY (SCanning Imaging Absorption spectroMeter for Atmospheric CartograpHY). It measures both the radiance component of the light reflected by the Sun-illuminated Earth's atmosphere and the direct Sun light. GOME-2 is a four channel UV/Vis grating spectrometer observing the Earth's atmosphere in nadir viewing geometry and covering the wavelength region of $240-790 \mathrm{~nm}$ at moderate spectral 
resolution of $0.2-0.4 \mathrm{~nm}$. It has a nominal ground-pixel size of $40 \times 80 \mathrm{~km}^{2}\left(240 \times 40 \mathrm{~km}^{2}\right.$ for the back scan $)$ over most of the globe. With its large swath of $1920 \mathrm{~km}$, near global coverage is achieved every day (Callies et al., 2000).

\section{Methods - data retrieval}

The differential optical absorption spectroscopy, DOAS (Platt, 1994), has been used to retrieve the GOME-2 slant column densities, $\mathrm{SCD}$, of $\mathrm{HCHO}, \mathrm{CHO} . \mathrm{CHO}$ and $\mathrm{NO}_{2}$. In brief, a high pass polynomial filter is applied to the optical depth to discriminate the narrow absorption bands of the trace gases from broad band extinction processes such as Rayleigh and Mie scattering and broad band molecular absorption. The SCDs are then converted to vertical column densities (VCDs) using air mass factors, AMFs, which account for the average light path length in the atmosphere. For the AMF computations the radiative transfer model SCIATRAN (Rozanov et al., 2005) was used.

For the $\mathrm{VCD}_{\mathrm{HCHO}}$ computation, the spectral window of $337-353 \mathrm{~nm}$ was chosen. Following the analysis described in Wittrock et al. (2006) for the SCIAMACHY instrument (Gottwald et al., 2006), the fitted polynomial is of the degree 5 and the reference absorption cross sections included in the retrieval procedure comprise $\mathrm{HCHO}$ (Meller and Moortgat, 2000), $\mathrm{O}_{3}$ (GOME-2 FM3), $\mathrm{NO}_{2}$ (GOME-2 FM3), $\mathrm{O}_{4}\left(\mathrm{O}_{2}-\right.$ $\mathrm{O}_{2}$ collision, Greenblatt et al., 1990), BrO (Fleischmann et al., 2004), and the pseudo-absorption features due to Rotational Raman Scattering (RRS) by air molecules (Ring effect, Vountas et al., 1998).

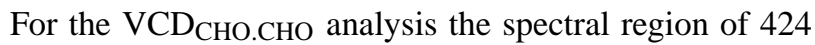
to 457 was selected. The absorption cross sections of CHO.CHO (Volkamer et al., 2005a), O 3 (GOME-2 FM3, Gür et al., 2005), $\mathrm{NO}_{2}$ (GOME-2 FM3) $\mathrm{O}_{4}$ (Greenblatt et al., 1990), water vapour (HITRAN database, http://www. cfa.harvard.edu/hitran/), a synthetic ring spectrum (Vountas et al., 1998) and a 4th order polynomial were used. Additional details on the retrieval procedure and on the AMF calculations used for the conversion of the $\mathrm{SCD}_{\mathrm{HCHO}}$ and $\mathrm{SCD}_{\mathrm{CHO} . \mathrm{CHO}}$ to VCDs can be found in Wittrock (2006), Wittrock et al. (2006) and Vrekoussis et al. (2009).

The $\mathrm{VCD}_{\mathrm{NO}_{2}}$ algorithm developed for the GOME and SCIAMACHY instruments (Richter and Burrows, 2002; Richter et al., 2005) has been applied to the GOME-2 spectra in the $425-497 \mathrm{~nm}$ spectral region. In addition to the $\mathrm{NO}_{2}$ cross section (GOME-2 FM3), $\mathrm{O}_{3}$ (GOME-2 FM3), $\mathrm{O}_{4}$ (Greenblatt et al., 1990), water vapour (Rothman et al., 1992), liquid water absorption (Pope and Frey, 1997), and a synthetic ring spectrum (Vountas et al., 1998) together with a 5th order polynomial were included in the DOAS retrieval.

Measurements with a cloud cover below $20 \%$ were used to minimize the biases induced by cloud shielding (Richter and Burrows, 2002; Vrekoussis et al., 2009) and no explicit cloud correction for the residual clouds was performed on the data. The presence of clouds can lead to an enhancement of absorption from the scene when the absorber is above the cloud, dependent on the ratio of the spectral reflectance of the clouds relative to that of the surface or to an underestimate, when the cloud is above the absorber. For this study, aimed at source assessment we consider this to be a reasonable approximation. The penetration depth of the photons to low altitudes, in the absence of clouds, strongly depends on wavelength for two independent reasons; (a) the scattering probability which decreases with increasing wavelength and (b) the reflectivity due to surface albedo which increases towards the visible part of the spectrum. It should be noted that although the photon light path is accounted for in the AMF calculations, differences between the real atmospheric situation and the assumptions made for the a priori conditions used in the AMF calculations may have a different impact on the vertical columns determined for $\mathrm{CHO}$. $\mathrm{CHO}$ and $\mathrm{HCHO}$ measurements because the AMF calculation are made for different spectral windows in the vis and uv region, respectively.

\section{Results and discussion}

\subsection{Global picture of $\mathrm{HCHO}$ and CHO.CHO}

Figure 1a and $\mathrm{b}$ depict the global composite maps of the tropospheric CHO.CHO and $\mathrm{HCHO}$ retrieved for the years 2007 and 2008. As for SCIAMACHY data (Wittrock et al., 2006; Vrekoussis et al., 2009) the pattern observed for both species is similar and point to their having common atmospheric sources. The retrieved GOME-2 column amounts of the two oxygenated VOCs species, OVOC, show enhanced values in the tropical and subtropical regions. Areas covered with dense vegetation and/or affected by biomass burning, mainly found in South America, Africa and Indonesia, have the highest retrieved columns of both CHO.CHO ( $\mathrm{VCD}_{\mathrm{CHO} . \mathrm{CHO}}>1 \times 10^{15} \mathrm{molec} \mathrm{cm}^{-2}$ ) and $\mathrm{HCHO}\left(\mathrm{VCD}_{\mathrm{HCHO}}>2 \times 10^{16} \mathrm{molec} \mathrm{cm}^{-2}\right.$ ). Polluted regions are also characterized by increased OVOC levels; over northeastern China the $\mathrm{VCD}_{\mathrm{CHO}}$.сHO and $\mathrm{VCD}_{\mathrm{HCHO}}$ exceed, on an annual basis, the levels of $5 \times 10^{15}$ molec $\mathrm{cm}^{-2}$ and $1.6 \times 10^{16}$ molec $\mathrm{cm}^{-2}$, respectively. Finally, moder-

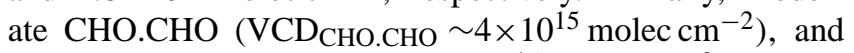
HCHO amounts $\mathrm{VCD}_{\mathrm{HCHO}} \sim 1 \times 10^{16} \mathrm{molec}^{-2}$ ) are observed over North America, Europe, India, and Australia. High values of $\mathrm{CHO}$.CHO are also observed, over oceans mainly in the tropics possibly due to the presence of biological active regions (Vrekoussis et al., 2009). This is in agreement with previous findings based on SCIAMACHY data (Wittrock et al., 2006; Vrekoussis et al., 2009). It is worth mentioning that the choice of a larger fitting window for the analysis of data from the GOME-2 instrument in comparison to the one used for SCIAMACHY (Wittrock et al., 2006; Vrekoussis et al., 2009) almost completely removes the artifact of negative values over the clear water oceanic regions 

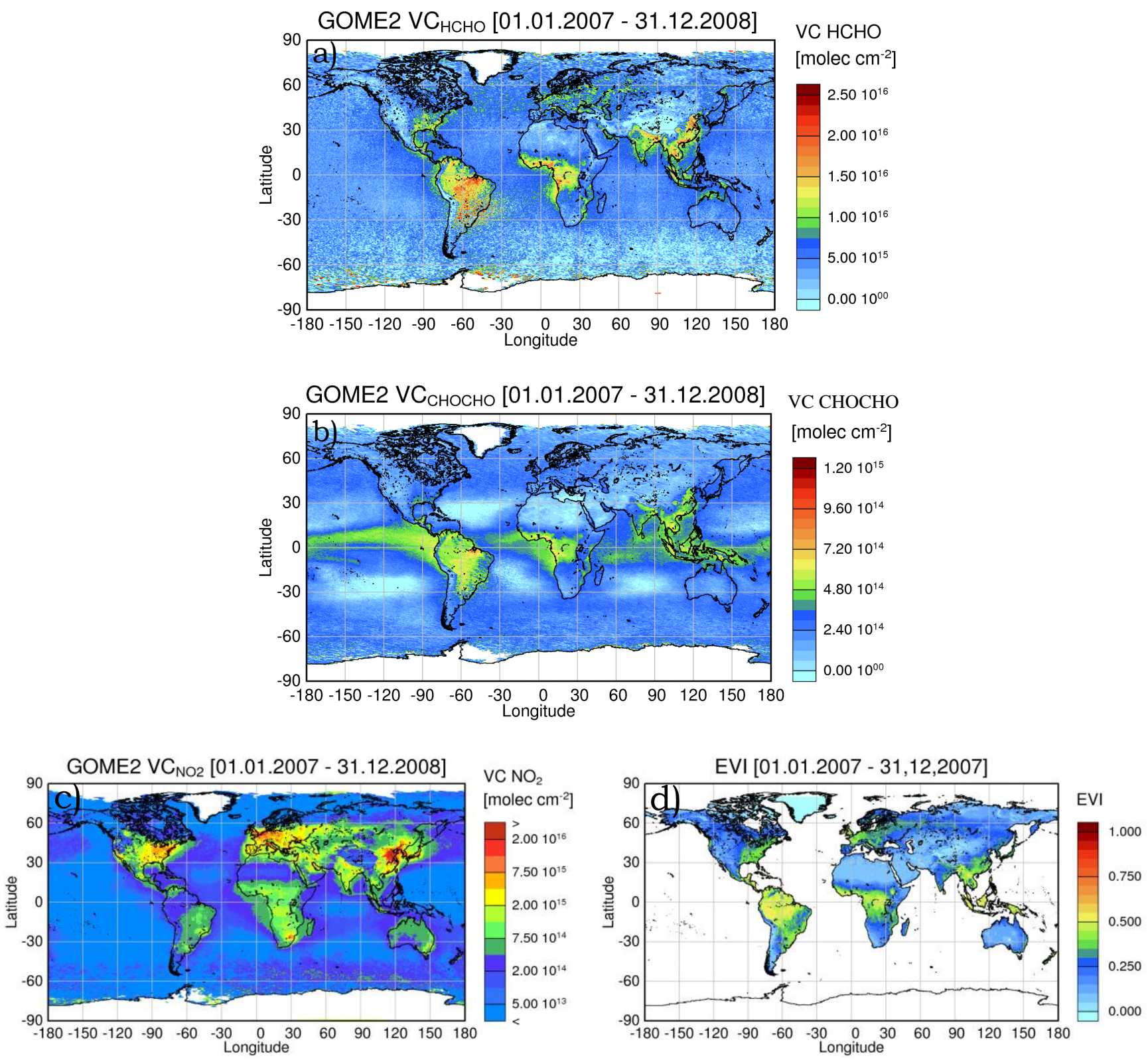

Fig. 1. Two years composite maps of the Vertical Column Densities $\left(\right.$ molec $\mathrm{cm}^{-2}$ ) of (a) $\mathrm{CHO} . \mathrm{CHO},(\mathbf{b}) \mathrm{HCHO}_{\text {, and }}(\mathbf{c}) \mathrm{NO}_{2} \mathrm{retrieved}$ using the radiance measurements of the GOME-2 instrument. Data gridded to $0.5^{\circ} \times 0.5^{\circ}$ have been used for the following analysis. Panel (d) depicts the average Enhanced Vegetation Index (EVI) computed for the period 2007-2008 using MODIS data (http://modis-land.gsfc. nasa.gov).

due to the interference with liquid water absorption and vibrational Raman scattering in the clear ocean. Mean values over these areas are now $-5 \times 10^{13}$ molec $\mathrm{cm}^{-2}$ which is very close to zero.

Except for these clear water regions, over parts of the oceans elevated CHO.CHO values are observed. The origin of these values is still under investigation. Recently, there was an increasing interest of many scientific research teams focusing onto this topic. Vrekoussis et al. (2009) pointed out that potential sources of these elevated values may be the convection of organic aerosols, which are rich in dissolved organic carbon, DOC, to the free troposphere. The existence of oxidants, such as $\mathrm{OH}, \mathrm{O}_{3}, \mathrm{NO}_{3}$ radicals and $\mathrm{IO}$ as well as other halogens will lead to the oxidation of the DOC and subsequently to the release of organic compounds and radicals to the atmosphere. Moreover, the regions where high CHO.CHO values are observed are often characterized as biological active ones with elevated amounts of phytoplankton. 
Table 1. Correlation between the column amounts of formaldehyde and glyoxal produced from the radiances of GOME-2 and SCIAMACHY instruments, over northeastern Asia, Africa, N. America, S. America and Europe. The highest square correlation coefficients, $R^{2}$, were found over NE. Asia and the lowest over Europe. On average for the selected regions, an overestimation of the VCD $\mathrm{HCHO}_{\mathrm{H} d}$ an underestimation of the $\mathrm{VCD}_{\mathrm{CHO}} \mathrm{CHO}$ are observed for the results based on the GOME-2 sensor in comparison to the SCIAMACHY ones.

\begin{tabular}{|c|c|c|c|c|c|c|c|}
\hline \multirow{2}{*}{ Region } & \multirow{2}{*}{ [Latitude, Longitude] } & \multicolumn{3}{|c|}{ GOME2 ${ }_{\mathrm{HCHO}}=\operatorname{aSCIA}_{\mathrm{HCHO}}, R^{2}$} & \multicolumn{3}{|c|}{$\mathrm{GOME}_{\mathrm{CHO}} \mathrm{CHO}=\mathrm{aSCIA}_{\mathrm{CHO} . \mathrm{CHO}}, R^{2}$} \\
\hline & & Fig. 2 & $\mathrm{a}$ & $R^{2}$ & Fig. 2 & $\mathrm{a}$ & $R^{2}$ \\
\hline NE. Asia & {$\left[5^{\circ} \mathrm{N}-40^{\circ} \mathrm{N}, 90^{\circ} \mathrm{E}-120^{\circ} \mathrm{E}\right]$} & $\mathrm{b}$ & 1.125 & 0.90 & $\mathrm{~h}$ & 0.925 & 0.87 \\
\hline Africa & {$\left[20^{\circ} \mathrm{S}-35^{\circ} \mathrm{N}, 16^{\circ} \mathrm{W}-40^{\circ} \mathrm{E}\right]$} & $\mathrm{c}$ & 1.064 & 0.79 & $\mathrm{i}$ & 0.918 & 0.80 \\
\hline N. America & {$\left[10^{\circ} \mathrm{N}-55^{\circ} \mathrm{N}, 130^{\circ} \mathrm{W}-60^{\circ} \mathrm{W}\right]$} & $\mathrm{d}$ & 1.177 & 0.69 & $\mathrm{j}$ & 0.999 & 0.76 \\
\hline S. America* & {$\left[20^{\circ} \mathrm{S}-10^{\circ} \mathrm{N}, 80^{\circ} \mathrm{W}-35^{\circ} \mathrm{W}\right]$} & e & 1.078 & 0.72 & $\mathrm{k}$ & 0.999 & 0.79 \\
\hline Europe & {$\left[35^{\circ} \mathrm{N}-55^{\circ} \mathrm{N}, 10^{\circ} \mathrm{W}-30^{\circ} \mathrm{E}\right]$} & $\mathrm{f}$ & 1.184 & 0.40 & 1 & 0.916 & 0.37 \\
\hline
\end{tabular}

* Excluding the pixels affected by the South Atlantic Anomaly.

This can be associated, in addition to the above mentioned DOC production and convection, with the release of various organic volatile organic compounds (e.g. isoprene). The direct oxidation of these VOC species can be another source of the observed CHO.CHO amounts. However, the oceanic sources of CHO.CHO as already stated by Vrekoussis et al. (2009) should be treated with caution as their interpretation is more demanding due to the potential interference from liquid water absorption and vibration Raman infilling of Fraunhofer lines in the spectral retrieval.

\subsection{Comparison of GOME-2 and SCIAMACHY values}

Satellite retrievals of OVOCs from GOME and later SCIAMACHY instruments are widely used as global input needed in model evaluations, emission estimates and to better understand the atmospheric chemistry linked to those species (e.g. Palmer et al., 2003, 2006; Millet at al., 2006, 2008; Fu et al., 2007, 2008; Myriokefalitakis et al., 2008; Dufour et al., 2009; Stavrakou et al., 2009b). However, the validation of the satellite retrievals of OVOCs with column amounts obtained by ground based remote instruments (e.g. Wittrock et al., 2006; Marbach et al., 2009; Vigouroux et al., 2009), aircraft data (Martin et al., 2006) and/or other space based instruments is still sparse. Figure 2 illustrates the first comparison of the retrieved GOME-2 $\mathrm{VCD}_{\mathrm{HCHO}}$ and $\mathrm{VCD}_{\mathrm{CHO}} \mathrm{CHO}$ with the respective VCDs computed from measurements of the SCIAMACHY instrument using the IUP-Bremen algorithms presented by Wittrock et al. (2006) and Vrekoussis et al. (2009). For the comparison all GOME-2 and SCIAMACHY data obtained between 2007 and 2008 were used, limiting the latitudinal range to $20^{\circ} \mathrm{S}-55^{\circ} \mathrm{N}$ over land, applying a $1^{\circ} \times 1^{\circ}$ gridding and excluding data over deserts as these are sometimes affected by retrieval artifacts. For the entire dataset, $\mathrm{VCD}_{\mathrm{HCHO}}$ (Fig. 2a) and $\mathrm{VCD}_{\mathrm{CHO}}$.CHO (Fig. 2g) show a very good correlation with a small underestimation of $5 \%$ for the CHO.CHO GOME-2 amounts and a small overestimation of $6 \%$ for the GOME-2 HCHO amounts.
To further investigate the degree of consistency between the two data sets, a more detailed comparison between GOME-2 and SCIAMACHY datasets was performed on a regional scale. Five large regions of interest were analysed separately: NE. Asia $\left[5^{\circ} \mathrm{N}-40^{\circ} \mathrm{N}, 90^{\circ} \mathrm{E}-120^{\circ} \mathrm{E}\right]$, Africa $\left[20^{\circ} \mathrm{S}-35^{\circ} \mathrm{N}, 16^{\circ} \mathrm{W}-40^{\circ} \mathrm{E}\right]$, S. America $\left[20^{\circ} \mathrm{S}-\right.$ $\left.10^{\circ} \mathrm{N}, 80^{\circ} \mathrm{W}-35^{\circ} \mathrm{W}\right]$, N. America $\left[10^{\circ} \mathrm{N}-55^{\circ} \mathrm{N}, 130 \mathrm{~W}-\right.$ $60 \mathrm{~W}]$ and Europe $\left[35^{\circ} \mathrm{N}-55^{\circ} \mathrm{N}, 10^{\circ} \mathrm{W}-30^{\circ} \mathrm{E}\right]$ and the results are presented in Table 1 and Fig. 2. The best correlation is found, for both species, over northeastern Asia (Fig. $2 \mathrm{~b}$ and h, red lines) and the worst over Europe (Fig. 2f and Fig. 1, light gray lines). For the selected five regions, the overestimation of the GOME-2 HCHO vertical column amounts ranged from $6 \%$ to $18 \%$ while the underestimation of the CHO.CHO GOME-2 column amounts was found to be between $0 \%$ and $6 \%$ (Table 1). It should be noted that in the analysis for S. America, the scenes over the South Atlantic magnetic Anomaly, SAA, were excluded because the detector noise spikes result in noise. Including these scenes in the analysis, results in the correlation of the HCHO column amounts for the two sensors being poor, with the square of the correlation coefficient being equal to 0.24 . Further work is required to remove the noisy detector elements from the fits of $\mathrm{HCHO}$ and $\mathrm{CHO}$. CHO in the SAA before these data can be used.

\subsection{Ratio $\boldsymbol{R}_{\mathrm{GF}}$ - "CHO.CHO to HCHO"}

The computation of the ratio of the columns of "glyoxal to formaldehyde", $R_{\mathrm{GF}}$, provides a valuable parameter for the characterization of sources. Different values of $R_{\mathrm{GF}}$ ratios are reported in the literature. For example, a previous study by Munger et al. (1995) held at the mountain ridge site in Shenandoah National Park, Virginia showed that the mean $R_{\mathrm{GF}}$ ratio was 0.045 . This value was linked to the biogenic emissions dominating this region. A similar value $(0.050)$ is calculated following a theoretical estimation based on the oxidation scheme of isoprene depicted by Spaulding 

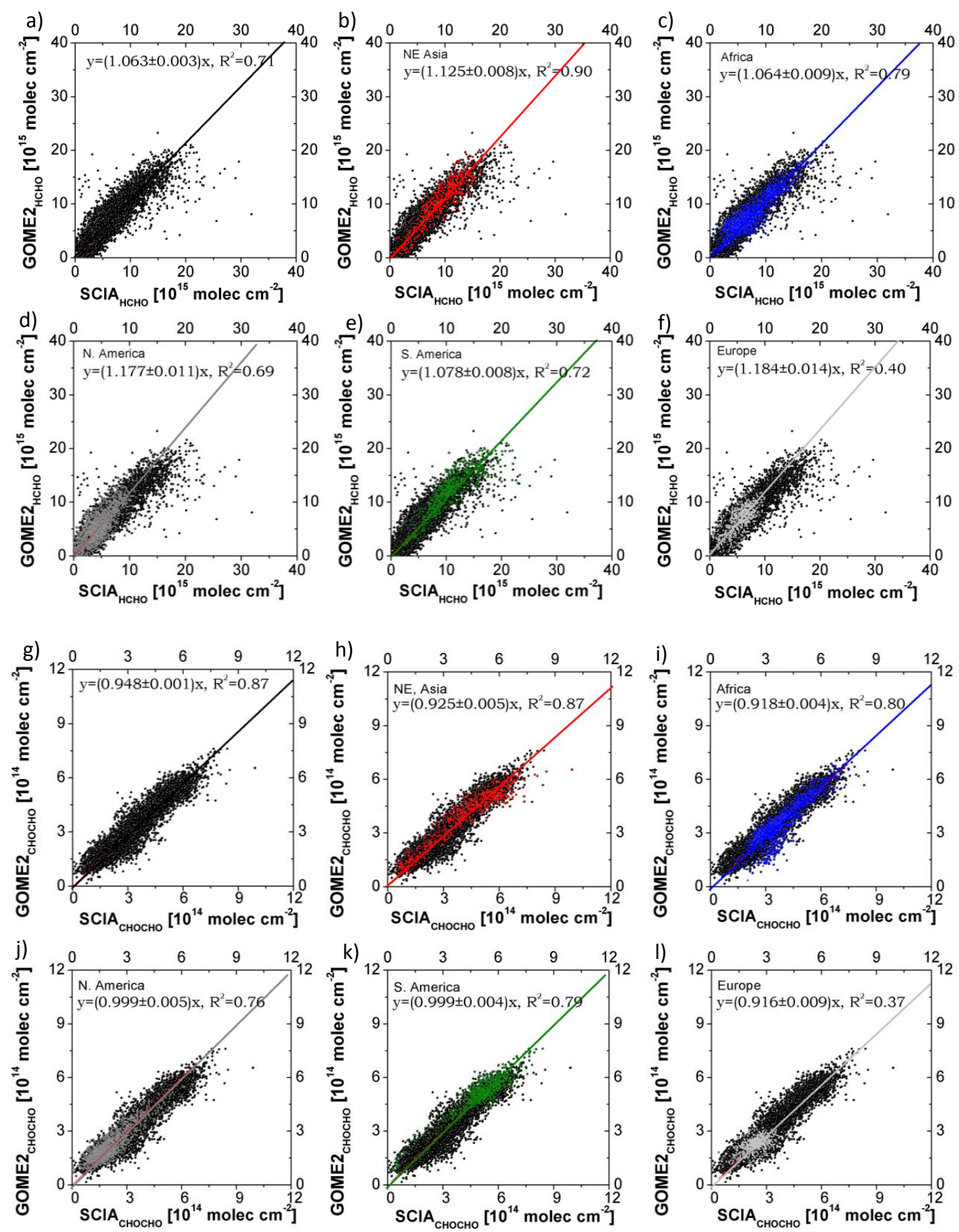

Fig. 2. Comparison between GOME-2 and SCIAMACHY retrieved $\mathrm{VCD}_{\mathrm{HCHO}}$ (Fig. 2a) and $\mathrm{VCD}_{\mathrm{HCHO}}$ (Fig. 2g) for the period 2007-2008 based on land data gridded at $\left[1^{\circ} \times 1^{\circ}\right]$ in the latitudinal range of $20^{\circ} \mathrm{S}$ to $55^{\circ} \mathrm{N}$ and excluding data over deserts as these are sometimes affected by retrieval artifacts. The black line depicts the linear fit regression line for the entire dataset. In addition, the correlation of the retrieved $\mathrm{VCD}_{\mathrm{HCHO}}$ and $\mathrm{VCD}_{\mathrm{CHO}} \mathrm{CHO}$ over northeastern Asia (Fig. $2 \mathrm{~b}$ and h, red colour), Africa (Fig. 2c and i, blue colour), N. America (Fig. 2d and j, grey colour), S. America (Fig. 2e and k, green) and Europe (Fig. 2f and 1, light grey colour) are shown. Linear fit regression lines are also plotted with the corresponding color.

et al. (2003). Later on, Volkamer et al. (2005b) presented a time series of the mixing ratio of $\mathrm{HCHO}$ and $\mathrm{CHO} . \mathrm{CHO}$ in the polluted Mexico City Metropolitan Area. For the common time period between 09:30 and 10:00, when concurrent satellite based observations of these trace gases occur by the sensors used in this study, the extracted $R_{\mathrm{GF}}$ was found to be lower than 0.040 . 

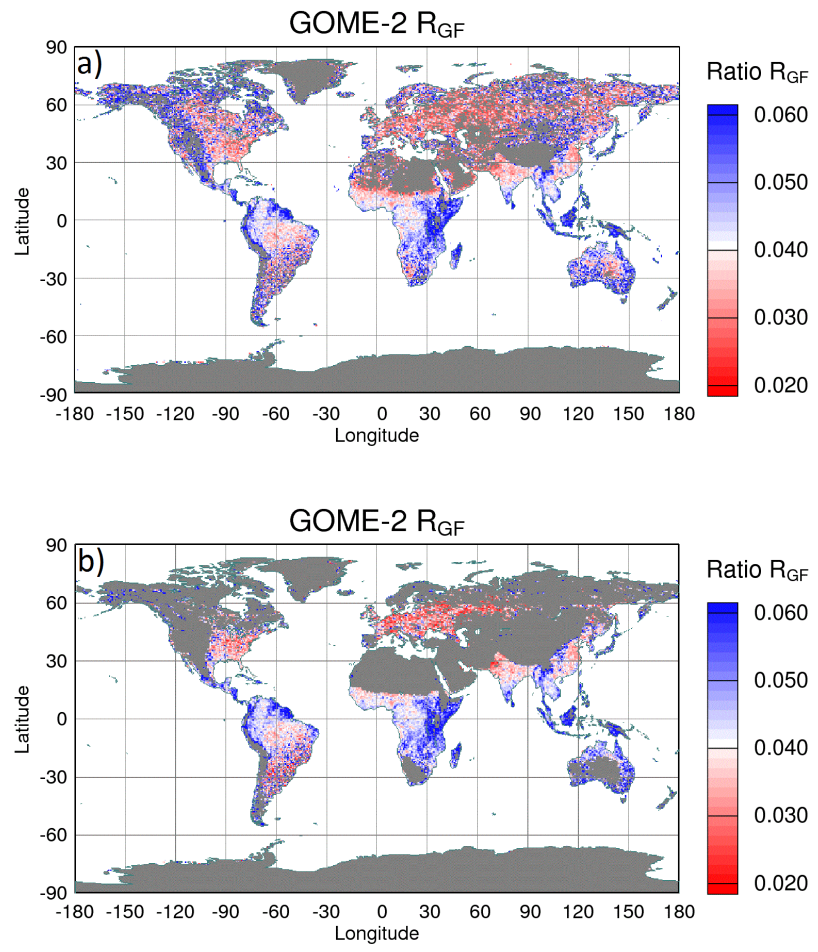

Fig. 3. (a) Global distribution over land of $R_{\mathrm{GF}}$, the ratio between glyoxal and formaldehyde vertical column averages of the two years. Blue colour depicts increases in $R_{\mathrm{GF}}$ values over 0.4 and red higher decreased below this threshold. Grey regions correspond to an absence of valid data due to large zenith angles, high surface reflectivity etc. Regions with dense population (e.g. China, Europe, and India) have lower $R_{\mathrm{GF}}$ values while regions with dense vegetation are characterized by higher $R_{\mathrm{GF}}$ values; (b) Same as before except the filtering out of the $\mathrm{VCD}_{\mathrm{CHO}} \mathrm{CHO}$ and $\mathrm{VCD}_{\mathrm{HCHO}}$ values close or below their detection limit of $2 \times 10^{14}$ molec cm $^{-2}$ and $2.5 \times 10^{15}$ molec $\mathrm{cm}^{-2}$ respectively, prior their division. The highest, blue values, are found over Indonesia and northeastern South America while the lowest, red ones, depict regions influenced by anthropogenic emissions.

The first attempts to investigate the range of this ratio for the identification of source types on a regional scale were reported by Wittrock et al. (2006) and Vrekoussis et al. (2009). Both studies used SCIAMACHY observations of HCHO and CHO.CHO but they were limited to selected and specific regions. It has been found that for places with known biogenic emissions (e.g. tropical forests), the $R_{\mathrm{GF}}$ lies within the range of $0.4-0.6$. In addition it was observed that regions characterized as polluted (e.g. northeast China) experience lower $R_{\mathrm{GF}}$ values than those dominated by biogenic influence.

This study goes one step further and takes advantage of the large swath of GOME-2 which provides almost daily global coverage. $\mathrm{VCD}_{\mathrm{CHO}} \mathrm{CHO}$ and $\mathrm{VCD}_{\mathrm{HCHO}}$ and subsequently the $R_{\mathrm{GF}}$ values were computed for the years 2007 to 2008 at a spatial resolution of $0.5^{\circ} \times 0.5^{\circ}$ (Fig. 3a). Although the individual ratios show a large scatter, the ratio of the two year averages shows the expected pattern of enhanced values of $R_{\mathrm{GF}}$ over biogenic source regions and low values in polluted areas. The same results are plotted in Fig. $3 \mathrm{~b}$ except that values of the vertical column densities of CHO.CHO and HCHO below or close to their detection limit have been omitted. Although in this case a large part of the $R_{\mathrm{GF}}$ values is removed, it is clearer that regions with anthropogenic activities experience lower $R_{\mathrm{GF}}$ values (red colour) in comparison to regions dominated by natural emissions (blue colour).

\subsubsection{Error analysis}

The accuracy of the vertical column amounts of trace gases depends on several individual systematic and non-systematic errors. For example the lack of precise knowledge on the absorption cross sections of the trace gases, the uncertainty in the computation of the air mass factors, instrumental errors, the noise of the measured backscattered electromagnetic radiation as a function of wavelength are among the key errors comprising the total uncertainty of the vertical column densities (e.g. Wittrock, 2006; De Smedt et al., 2008; Vrekoussis et al., 2009). From previous estimations the total monthly uncertainty for $\mathrm{CHO} . \mathrm{CHO}$ is given by:

$\left[2.0 \times 10^{14}\right.$ molec $\left.^{-2}+X \mathrm{VCD}_{\mathrm{CHO}} \mathrm{CHO}\right]$

and for $\mathrm{HCHO}$ by:

$\left[2.5 \times 10^{15}\right.$ molec $\left.^{-2}+Y \mathrm{VCD}{ }_{\mathrm{HCHO}}\right]$

where $X, Y$ are strongly ground scene dependant and vary typically in the range of 0.1 to 0.3 .

The error of the $R_{\mathrm{GF}}$ ratio is then calculated as follows:

$R_{\mathrm{GF}}=\frac{[\mathrm{CHO} . \mathrm{CHO}]}{[\mathrm{HCHO}]}=\frac{a}{b}$

where $a=[\mathrm{CHO} . \mathrm{CHO}]$, the glyoxal vertical column and $b=[\mathrm{HCHO}]$, the formaldehyde vertical column. The standard deviation of this ratio is calculated using standard error propagation:

$\operatorname{sd}_{\mathrm{RGF}}=\frac{\vartheta \mathrm{a}}{\vartheta \mathrm{b}}=\sqrt{\left(\frac{\vartheta \mathrm{R}}{\vartheta \mathrm{a}}\right)^{2} \mathrm{sd}_{\mathrm{a}}^{2}+\left(\frac{\vartheta \mathrm{R}}{\vartheta \mathrm{b}}\right)^{2} \mathrm{sd}_{\mathrm{b}}^{2}}$
$=\sqrt{\frac{1}{\mathrm{~b}^{2}} \mathrm{sd}_{\mathrm{a}}^{2}+\frac{\mathrm{a}^{2}}{\mathrm{~b}^{4}} \mathrm{sd}_{\mathrm{b}}^{2}}=\frac{1}{\mathrm{~b}} \sqrt{\mathrm{sd}_{\mathrm{a}}^{2}+\left(\frac{\mathrm{a}}{\mathrm{b}}\right)^{2} \mathrm{sd}_{\mathrm{b}}^{2}}$

or

$\mathrm{sd}_{\mathrm{RGF}}=\frac{1}{[\mathrm{HCHO}]} \sqrt{\mathrm{sd}^{2}{ }_{\mathrm{CHO} . \mathrm{CHO}}+\left(\frac{[\mathrm{CHO} . \mathrm{CHO}]}{[\mathrm{HCHO}]}\right)^{2} \mathrm{sd}^{2}{ }_{\mathrm{HCHO}}}$

The random component of the uncertainty of the individual trace gases depends on the spatial resolution (which is 
Table 2. Median values of the GOME-2 and SCIAMACHY column amounts of glyoxal and formaldehyde coupled with their average ratio, $R_{\mathrm{GF}}$. The GOME-2 and SCIAMACHY $R_{\mathrm{GF}} 2007-2008$ over 12 selected regions are compared to the median SCIAMACHY $R_{\mathrm{GFM}}$ data of the period 2003-2007 which were presented to Vrekoussis et al. (2009). Data gridded to $0.5^{\circ} \times 0.5^{\circ}$ have been used for the following analysis.

\begin{tabular}{|c|c|c|c|c|c|c|c|c|c|c|c|}
\hline & \multirow[b]{2}{*}{$\begin{array}{c}\text { Lat } \\
\text { Center } \\
\text { [deg] }\end{array}$} & \multirow[b]{2}{*}{$\begin{array}{c}\text { Long } \\
\text { Center } \\
{[\mathrm{deg}]}\end{array}$} & \multicolumn{3}{|c|}{$\begin{array}{c}\text { GOME-2 } \\
\text { [2007-2008] }\end{array}$} & \multicolumn{3}{|c|}{$\begin{array}{c}\text { SCIAMACHY } \\
\text { [2007-2008] }\end{array}$} & \multicolumn{3}{|c|}{$\begin{array}{l}\text { SCIAMACHY } \\
\text { [2003-2007] }^{\mathrm{a}}\end{array}$} \\
\hline & & & $\begin{array}{c}\text { CHO.CHO } \\
{\left[10^{14} \text { molec }\right.} \\
\left.\mathrm{cm}^{-2}\right]\end{array}$ & $\begin{array}{c}\mathrm{HCHO} \\
{\left[10^{15} \text { molec }\right.} \\
\left.\mathrm{cm}^{-2}\right]\end{array}$ & $\begin{array}{c}R_{\mathrm{GF}} \\
\text { GOME2 }\end{array}$ & $\begin{array}{c}\text { CHO.CHO } \\
{\left[10^{14} \text { molec }\right.} \\
\left.\mathrm{cm}^{-2}\right]\end{array}$ & $\begin{array}{c}\text { HCHO } \\
{\left[10^{15} \text { molec }\right.} \\
\left.\mathrm{cm}^{-2}\right]\end{array}$ & $\begin{array}{l}R_{\mathrm{GF}} \\
\text { SCIA }\end{array}$ & $\begin{array}{c}\text { CHO.CHO } \\
{\left[10^{14} \text { molec }\right.} \\
\left.\mathrm{cm}^{-2}\right]\end{array}$ & $\begin{array}{c}\mathrm{HCHO} \\
{\left[10^{15} \mathrm{molec}\right.} \\
\left.\mathrm{cm}^{-2}\right]\end{array}$ & $\begin{array}{c}R_{\mathrm{GFM}} \\
\text { SCIA }\end{array}$ \\
\hline USA & $32 \pm 4$ & $-90 \pm 10$ & 3.66 & 8.89 & $0.041 \pm 0.009$ & 3.86 & 8.02 & $0.048 \pm 0.010$ & 3.67 & 8.07 & 0.045 \\
\hline S. America (1) & $0 \pm 10$ & $-62 \pm 8$ & 5.22 & 12.63 & $0.041 \pm 0.009$ & 5.29 & 11.53 & $0.046 \pm 0.010$ & 5.32 & 12.5 & 0.043 \\
\hline S. America (2) & $-2 \pm 4$ & $-50 \pm 3$ & 7.05 & 15.51 & $0.045 \pm 0.010$ & 7.24 & 14.99 & $0.048 \pm 0.010$ & 6.62 & 13.8 & 0.048 \\
\hline Africa_N & $6 \pm 4$ & $1 \pm 10$ & 5.77 & 12.17 & $0.047 \pm 0.010$ & 6.06 & 11.58 & $0.052 \pm 0.011$ & 5.83 & 11.4 & 0.051 \\
\hline Africa_E & $2 \pm 4$ & $19 \pm 9$ & 5.04 & 12.22 & $0.041 \pm 0.009$ & 5.11 & 12.08 & $0.042 \pm 0.009$ & 5.36 & 12.9 & 0.042 \\
\hline Africa_S & $-7 \pm 5$ & $19 \pm 9$ & 4.63 & 10.87 & $0.043 \pm 0.009$ & 4.79 & 10.68 & $0.045 \pm 0.010$ & 5.05 & 11.0 & 0.046 \\
\hline Indonesia & $2 \pm 6$ & $108 \pm 12$ & 5.19 & 8.6 & $0.060 \pm 0.013$ & 5.59 & 7.85 & $0.071 \pm 0.015$ & 5.54 & 8.34 & 0.066 \\
\hline Australia & $-14 \pm 3$ & $135 \pm 10$ & 3.69 & 6.72 & $0.055 \pm 0.012$ & 4.01 & 6.83 & $0.059 \pm 0.012$ & 3.75 & 6.09 & 0.062 \\
\hline Asia_S & $25 \pm 3$ & $112 \pm 5$ & 5.27 & 12.34 & $0.043 \pm 0.009$ & 5.69 & 11.89 & $0.048 \pm 0.010$ & 5.79 & 12.5 & 0.046 \\
\hline Asia_N & $34 \pm 5$ & $116 \pm 5$ & 5.01 & 13.88 & $0.036 \pm 0.008$ & 5.28 & 13.54 & $0.039 \pm 0.008$ & 4.52 & 11.9 & 0.038 \\
\hline India & $24 \pm 4$ & $85 \pm 7$ & 4.52 & 10.7 & $0.042 \pm 0.009$ & 4.75 & 9.96 & $0.048 \pm 0.010$ & 4.88 & 9.14 & 0.053 \\
\hline Europe & $48 \pm 5$ & $7 \pm 6$ & 2.37 & 8.15 & $0.029 \pm 0.006$ & 2.29 & 6.98 & $0.033 \pm 0.007$ & 2.20 & 7.32 & 0.034 \\
\hline
\end{tabular}

a based on Vrekoussis et al., 2009.

$0.125^{\circ} \times 0.125^{\circ}$ in the original data sets) and on the temporal resolution (which is one month). However, as the results presented in this study are averaged in space and time, the random uncertainties are further reduced by $\sqrt{\left(\frac{1}{D x D}\right)}$ (where D is the ratio of the coarse to fine spatial resolution) and $\sqrt{\left(\frac{1}{n}\right)}$ (temporal resolution is $\mathrm{n}$ months).

The spatiotemporal averaging applies only for the random component of the error and not the systematic. The main components of the systematic errors emanate from the uncertainties of the absorption cross sections (SC systematic error) and the uncertainties on the air mass factor calculations (AMF systematic error). The latter can be seen as being partly random as variations in vertical profile and clouds over time do cancel to some degree. Other sources of systematic errors are the instrumental and misfit effects (De Smedt et al., 2008). The SC systematic error is estimated to be about $15 \%$ for both species for the selected latitudinal range of the current study (Wittrock, 2006; De Smedt et al., 2008). Assuming similar profiles for the HCHO and CHO.CHO, the uncertainty of the ratio of the two species attributed to the AMF systematic error is expected to cancel out to a large part in spite of the difference in wavelength range used for the retrieval.

The total error will comprise the random and the systematic error; for a time period of two years, 2007-2008, and for a typical ground scene where $\mathrm{VCD}_{\mathrm{HCHO}}=7.0 \times 10^{15}$ molec $\mathrm{cm}^{-2}$ and $\mathrm{VCD}_{\mathrm{CHO} . \mathrm{CHO}}=3.0 \times 10^{14} \mathrm{molec} \mathrm{cm}^{-2}$ the random error of the $R_{\mathrm{GF}}$ ratio as computed from Eq. (5) and based on the reduction of the $\mathrm{HCHO}$ and $\mathrm{CHO}$. CHO uncertainties due to the temporal $\sqrt{\left(\frac{1}{24}\right)}$ and spatial $\sqrt{\left(\frac{1}{4 \times 4}\right)}$ av- eraging used is equal to 0.003 . The systematic error is not reduced as the random one; based on the aforementioned estimation $(15 \%)$, the systematic uncertainty for the ratio as computed from Eq. (5) is about 0.008 . Thus the total uncertainty of the $R_{\mathrm{GF}}$ ratio (and not that of the individual species) is 0.011 which is about $31 \%$ and $22 \%$ of the typical values of 0.035 and 0.050 determined for a ground scene dominated by anthropogenic and biogenic emissions respectively (see Sects. 3.4.1 and 3.4.2).

\subsubsection{Comparison of GOME-2 and SCIAMACHY $\boldsymbol{R}_{\mathrm{GF}}$ values}

In order to extend the comparison of GOME-2 and SCIAMACHY results, the $R_{\mathrm{GF}}$ dataset retrieved from the radiances measured by the GOME-2 instrument was compared with the SCIAMACHY based values reported by Vrekoussis et al. (2009, Table 2). The median values of GOME-2 VCDs of CHO.CHO and HCHO, coupled with their $R_{\mathrm{GF}}$ ratio, were computed over 12 areas over N. America, S. America, Africa, Indonesia, Australia, Eastern Asia, India and Europe (Table 2) for the years 2007 and 2008. The SCIAMACHY VCDs of HCHO and CHO.CHO were also analyzed for the period 2007 to 2008 complementing the SCIAMACHY dataset of VCDs obtained for the extended period of 5 years, from 2003 to 2007 and presented in Vrekoussis et al. (2009).

Over these regions of interest, the mean value of the median GOME-2 $\mathrm{VCD}_{\mathrm{CHO}} \mathrm{CHO}$ was found to be equal to $4.8 \times 10^{14} \mathrm{molec} \mathrm{cm}^{-2}$ which is in agreement with the respective SCIAMACHY $\mathrm{VCD}_{\mathrm{CHO} \text {.CHO, not only }}$ for the same time period $\left(5.0 \times 10^{14}\right.$ molec $\left.\mathrm{cm}^{-2}\right)$ but also for the extended period of 5 years $\left(4.9 \times 10^{14}\right.$ molec $\mathrm{cm}^{-2}$ ). The average GOME-2 column amounts 

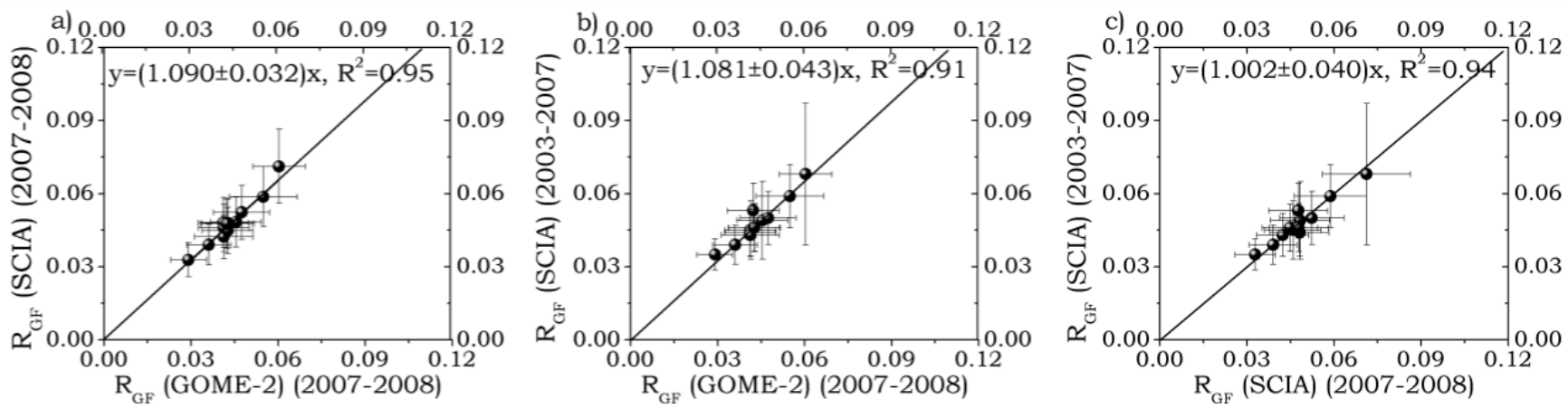

Fig. 4. Correlation plots of the regional averages of GOME-2 and SCIAMACHY $R_{\mathrm{GF}}$ values (presented also in Table 2) coupled with their standard deviation. Figure 4 a illustrates the correlation of GOME- $2 R_{\mathrm{GF}}$ data with the respective SCIAMACHY data for the same period (2007-2008) while comparison with the SCIAMACHY period 2003-2007 is shown in Fig. 4b. Figure 4c compares directly the above mentioned SCIAMACHY datasets. SCIAMACHY $R_{\mathrm{GF}}$ values are about $8-9 \%$ higher than the respective GOME-2 ones while the two SCIAMACHY datasets show a 1:1 relationship indicating that the values did not change significantly over time.

of HCHO (GOME-2 $\mathrm{VCD}_{\mathrm{HCHO}}=1.11 \times 10^{16} \mathrm{molec} \mathrm{cm}^{-2}$ ) are slightly larger than those of the SCIAMACHY ones for the 2007-2008 period $\left(\mathrm{VCD}_{\mathrm{HCHO}(\mathrm{SCIA})}=1.05 \times 10^{16}\right.$ molec $\mathrm{cm}^{-2}$ ) and also than the 2003-2007 period data $\left(\mathrm{VCD}_{\mathrm{HCHO}}(\mathrm{SCIA})=1.05 \times 10^{16}\right.$ molec $\left.\mathrm{cm}^{-2}\right)$. For both sensors, the lowest CHO.CHO to HCHO ratio was found over Europe and northeast Asia and the highest over Indonesia, the second highest over by Australia. Figure 4 depicts the correlation of the regional average $R_{\mathrm{GF}}$ (not median) values of GOME-2 and SCIAMACHY for the period 20072008 (Fig. 4a), of GOME-2 and SCIAMACHY for the period 2003-2008 (Fig. 4b) and that of the two SCIAMACHY datasets (Fig. 4c) coupled to their standard deviations. In all three cases the correlation is very good $\left(R^{2}>0.91\right)$. The slope of the regression line between the two SCIAMACHY datasets is almost one, while for the other two pairs the SCIAMACHY $R_{\mathrm{GF}} \mathrm{S}$ are $8-9 \%$ higher than the GOME-2 ones.

\section{4 $R_{\mathrm{GF}}$ and emission sources}

The individual monthly mean values between the latitudinal range of $20^{\circ} \mathrm{S}$ to $55^{\circ} \mathrm{N}$ (in total 24 months and 450000 points) of both $\mathrm{HCHO}$ and $\mathrm{CHO}$.CHO have been analyzed. Figure 5 illustrates the 2-D frequency analysis for the retrieved $\mathrm{VCD}_{\mathrm{HCHO}}$ and $\mathrm{VCD}_{\mathrm{CHO}} \mathrm{CHO}$ or in other words, the number of $0.5^{\circ}$ grid cells for each CHO.CHO-HCHO pair. A clear positive correlation is observed between CHO.CHO and $\mathrm{HCHO}$ in spite of the high variability. When focusing on the binned $\mathrm{VCD}_{\mathrm{CHO}}$.CHO values per $5 \times 10^{14}$ molec $^{-2}$ of $\mathrm{VCD}_{\mathrm{HCHO}}$ (blue dots) and more specifically on the region where the majority of the paired values occur (black colour), a slope of $R_{\mathrm{GF}}=0.043 \pm 0.005$ (white dashed line) with a squared correlation coefficient of 0.98 is computed. This strong correlation, which is a product of two independent retrievals of $\mathrm{HCHO}$ and $\mathrm{CHO} . \mathrm{CHO}$ in two separate spectral

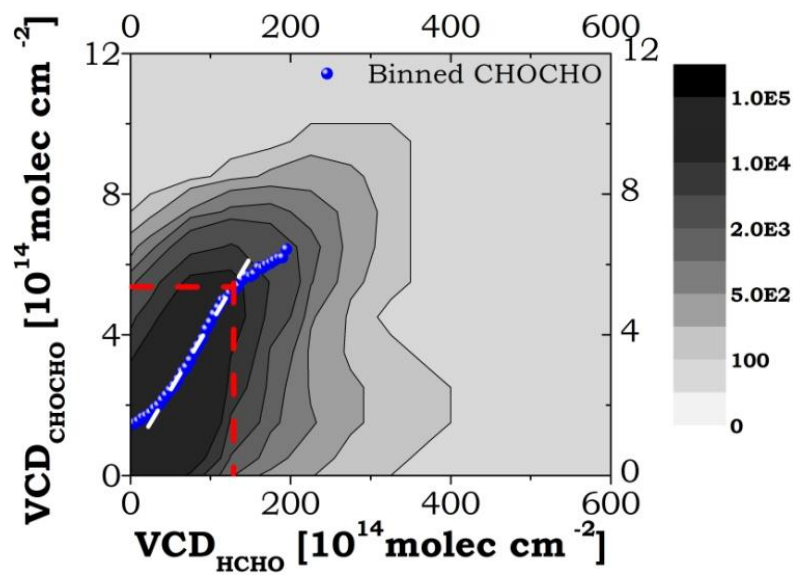

Fig. 5. 2-D frequency analysis of the $\mathrm{VCD}_{\mathrm{CHO}} \mathrm{CHO}$ and $\mathrm{VCD}_{\mathrm{HCHO}}$ showing the number of $0.5^{\circ} \times 0.5^{\circ}$ monthly grid cells for each pair of $\mathrm{VCD}_{\mathrm{CHO}} \mathrm{CHO}^{-} \mathrm{VCD}_{\mathrm{HCHO}}$ measurements. Darker colours point at a higher occurrence number of a value combination. The blue dots are the binned $\mathrm{VCD}_{\mathrm{CHO}} \mathrm{CHO}$ data per $5 \times 10^{14}$ molec $\mathrm{cm}^{-2}$ of $\mathrm{VCD}_{\mathrm{HCHO}}$ and the white line depicts the linear regression fit for the region with the higher density of paired values. For clarity reasons, only the positive vertical column densities of CHO.CHO and $\mathrm{HCHO}$ are presented.

regions (uv and visible) points to common emission sources for both species.

It should be noted that for the current study we discarded the "biomass burning" pixels, for both trace gases, which were identified using fire counts from the Advanced Along Track Scanning Radiometer, AATSR (ATSR World Fire Atlas, http://dup.esrin.esa.int/ionia/wfa/index.asp). The main reason of this decision is the complexity of the different fires. Depending on the type of fire and depending on the region where they take place, they are connected/or not with the 

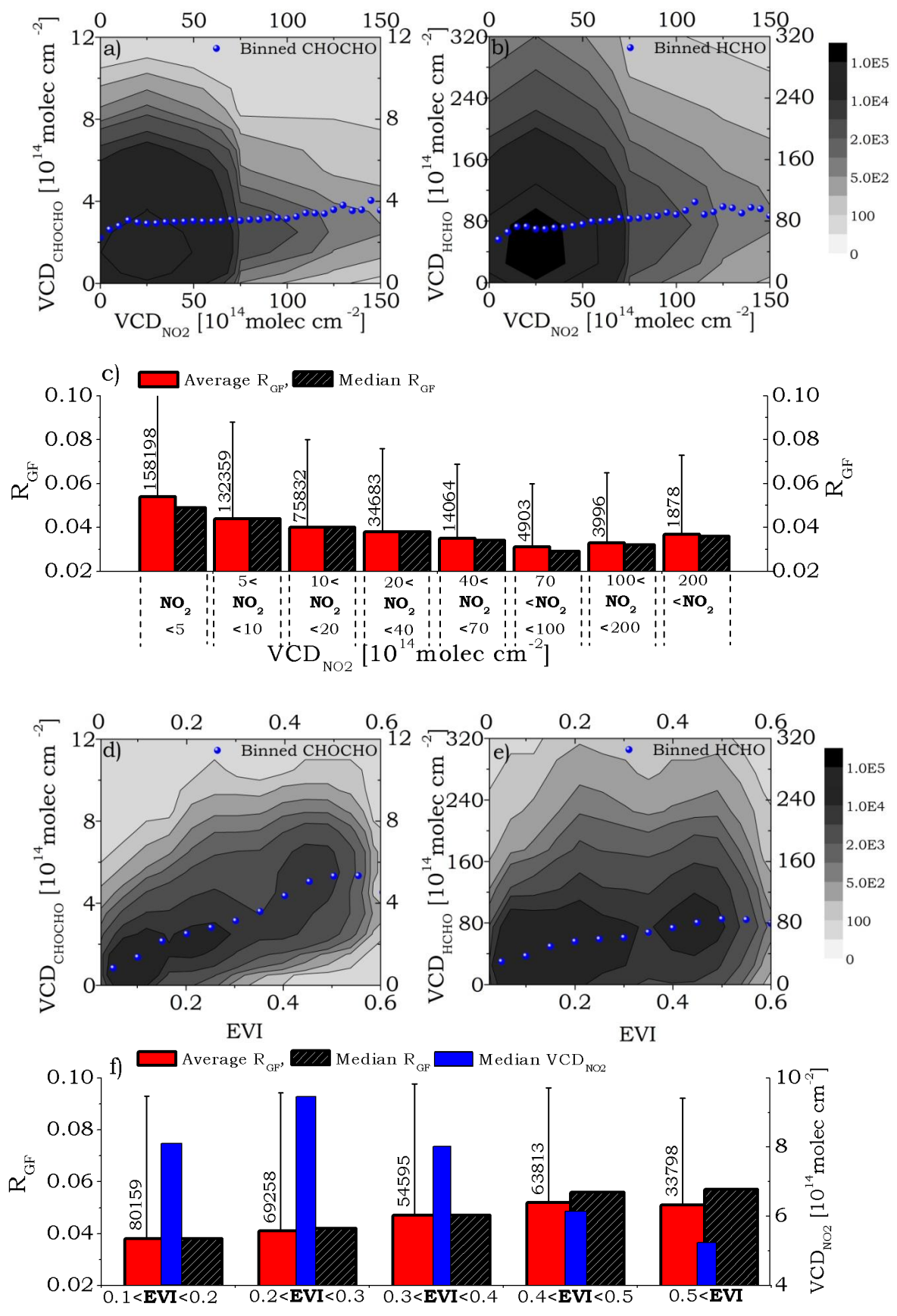

EVI

Fig. 6. 2-D frequency analysis of $\mathrm{VCD}_{\mathrm{CHO}} \mathrm{CHO}$ and $\mathrm{VCD}_{\mathrm{NO}_{2}}$ (panel a), $\mathrm{VCD}_{\mathrm{HCHO}}$ and $\mathrm{VCD}_{\mathrm{NO}_{2}}$ (panel b), $\mathrm{VCD} \mathrm{CHO}_{\mathrm{CHO}}$ and EVI (panel d), $\mathrm{VCD}_{\mathrm{HCHO}}$ and EVI (panel e). Blue dots are the binned OVOCs per $5 \times 10^{14}$ molec $\mathrm{cm}^{-2}$ of $\mathrm{NO}_{2}$ and 0.05 units of EVI, respectively. Panels (c) and (f) present the average (red bars) and median (black bars) $R_{\mathrm{GF}}$ ratios as a function of various $\mathrm{NO}_{2}$ and EVI levels, respectively. For a given group of $\mathrm{NO}_{2}$ column amounts covering non polluted to polluted conditions and of EVI values covering bare land to vegetated areas, the ratio of the column amounts of glyoxal to formaldehyde is computed. The blue bars of panel (f) represent the $\mathrm{NO}_{2}$ levels computed for each of the EVI categories. The numbers close to the side of the standard deviations coupled to the average $R_{\mathrm{GF}}$ denote the number of pairs used in the analysis of the ratios. 
presence of nitrogen dioxide. Therefore there is no homogeneity which will allow us to categorize them as one group. For this reason we chose to address this topic separately in a forthcoming manuscript.

\subsection{1 $R_{\mathrm{GF}}$ and anthropogenic emissions}

Figure 5 includes all the values of the observed VCDs of $\mathrm{HCHO}$ and $\mathrm{CHO}$.CHO. In order to estimate the influence of the anthropogenic emissions on the computed $R_{\mathrm{GF}}$ ratio, the $\mathrm{VCD}_{\mathrm{NO}_{2}}$ from GOME-2 (Fig. 1c) were used. The reason for choosing $\mathrm{NO}_{2}$ as an anthropogenic tracer emanates from its main source; the combustion of fossil fuels (Lee et al., 1997). Following an approach similar to the one used for Fig. 5, the 2-D frequency analysis based on the monthly mean $0.5^{\circ}$ grid cells of $\mathrm{CHO}$. CHO and $\mathrm{NO}_{2}$ (Fig. 6a) and that of $\mathrm{HCHO}$ and $\mathrm{NO}_{2}$ (Fig. 6b) has been performed. The blue dots depict the binned CHO.CHO and $\mathrm{HCHO}$ values per $5.0 \times 10^{14}$ molec cm ${ }^{-2}$ of $\mathrm{VCD}_{\mathrm{NO}_{2}}$, respectively. Both species show only a small increase towards large $\mathrm{NO}_{2}$ columns; $\mathrm{CHO}$.CHO grows from 2.5 to $4.0 \times 10^{14}$ molec cm ${ }^{-2}$ when $\mathrm{NO}_{2}$ increases from non polluted conditions $\left(1.0 \times 10^{15}\right.$ molec cm $\left.\mathrm{cm}^{-2}\right)$ to heavily polluted conditions $\left(\sim 1.5 \times 10^{16} \mathrm{molec}^{-2}\right)$ while the respective

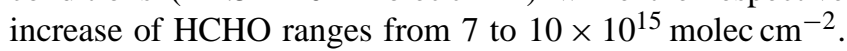
As can be seen, neither HCHO nor CHO.CHO columns are strongly linked to $\mathrm{NO}_{2}$ amounts and thus pollution levels. However, the changes, although small, have a systematic impact on the $R_{\mathrm{GF}}$ values which turn out to be a function of the pollution level. Figure $6 \mathrm{c}$ illustrates the $R_{\mathrm{GF}}$ ratio as a function of various $\mathrm{NO}_{2}$ levels covering conditions from a clean to an extremely polluted environment. Each bar depicts the average $R_{\mathrm{GF}}$ value (redcolumns) for a given $\mathrm{NO}_{2}$ range, coupled to the computed standard deviation of the ratio. In addition the median $R_{\mathrm{GF}}, R_{\mathrm{GFM}}$, is also presented (black columns). When $\mathrm{NO}_{2}$ values are close to zero, $R_{\mathrm{GFM}}$ is equal to 0.050 . This value gradually decreases as the levels of $\mathrm{NO}_{2}$ increase. Before continuing it should be noted that the presence of urban aerosols is accounted for in the AMF calculations for both $\mathrm{HCHO}$ and $\mathrm{CHO}$. CHO. Any potential changes in the uncertainty of the ratio of $\mathrm{HCHO}$ and CHO.CHO induced by changes of the aerosol content is expected to cancel out.

For typical urban conditions $\left(\mathrm{NO}_{2}>4 \times 10^{15}\right.$ molec $\mathrm{cm}^{-2}$ ), $R_{\mathrm{GFM}}$ drops below the limit of 0.040 and under heavy pollution $\left(\mathrm{NO}_{2} \sim 1 \times 10^{16}\right.$ molec $\left.\mathrm{cm}^{-2}\right), R_{\mathrm{GFM}}$ is lower than 0.030 . The decrease of $R_{\mathrm{GF}}$ can be explained by the existence of anthropogenic primary sources of $\mathrm{HCHO}$ in addition to the secondary sources for both, CHO.CHO and HCHO. Lastly, when the $\mathrm{VCD}_{\mathrm{NO}_{2}}$ is extremely high ( $>1 \times 10^{16}$ molec $^{-2}$ ) the $R_{\mathrm{GFM}}$ increases again up to the value of 0.036 . This behavior could be indicative of a potential compensation point of $R_{\mathrm{GFM}}$ being equal to 0.030 , where the balance between the levels of CHO.CHO and HCHO is disturbed. A possible explanation is that under polluted con- ditions an enhancement to the levels of acetylene and aromatics is observed. The latter are high yield anthropogenic precursors of CHO.CHO (Myriokefalitakis et al., 2008 and references therein). Nevertheless, the last groups of $\mathrm{NO}_{2}$ should be treated with care as they represent less than the $0.5 \%$ of the total $R_{\mathrm{GF}}$ values and could be the result of special pollution situations as e.g. found in parts of China having different VOC emission patterns and at the same time very high $\mathrm{NO}_{2}$ levels.

\subsection{2 $R_{\mathrm{GF}}$ and biogenic emissions}

The average Enhanced Vegetation Index, EVI from the Terra Moderate Resolution Imaging Spectroradiometer (MODIS) sensor (Justice et al., 1998) of the period 2007-2008 (Fig. 1d) has been used to examine the relationship between vegetation and the calculated $R_{\mathrm{GF}}$ ratio. For this reason the monthly mean EVI $0.5^{\circ} \times 0.5^{\circ}$ values were plotted together with the VCDs of CHO.CHO (Fig. 6d) and HCHO (Fig. 6e). The binned OVOCs per 0.05 units of EVI revealed that for both species a positive correlation with the EVI exists. CHO.CHO increases from almost 0 to $5 \times 10^{14} \mathrm{molec} \mathrm{cm}^{-2}$ and HCHO from $3 \times 10^{15} \mathrm{molec} \mathrm{cm}^{-2}$ to $8 \times 10^{15} \mathrm{molec} \mathrm{cm}^{-2}$ when moving from barren areas (EVI $<0.2$, Carrão et al., 2007) to densely vegetated regions. A direct connection of the observed HCHO with both EVI and Leaf Area Index (Hassan and Bourque, 2010) has also been reported by Barkley et al. (2009) showing that the observed decrease in HCHO is consistent with the variations in vegetation.

The observed positive correlation verifies that both $\mathrm{HCHO}$ and CHO.CHO are high yield products of the isoprene oxidation scheme (Spaulding et al., 2003; Fu et al., 2008; Stavrakou et al., 2009) and also underlines that the levels of these OVOCs are higher under the oxidation of the biogenic precursors in comparison to the anthropogenic ones.

For each group of EVI equal to 0.1 , the average $R_{\mathrm{GF}}$ was calculated (Fig. 6f). The respective analysis disclosed a progressive increase of the $R_{\mathrm{GF}}$ with increasing EVI indicating that either the oxidation of the biogenic precursors such as isoprene and terpenes favors glyoxal production or more $\mathrm{CHO}$. $\mathrm{CHO}$ than $\mathrm{HCHO}$ remains in the gas phase. For EVI values greater than 0.2 the $R_{\mathrm{GF}}$ exceeds the limit of 0.04 reaching up to almost 0.06 for the highest EVIs. This range is in agreement with the respective SCIAMACHY values reported by Vrekoussis et al., 2009 for the regions controlled by biogenic emissions. For the same EVI groups of 0.1 units, the $\mathrm{VCD}_{\mathrm{NO}_{2}}$ levels were calculated (Fig. 6f, blue bars) in order to examine the potential additional influence of the anthropogenic emissions on the computed $R_{\mathrm{GF}}$ ratio. It was found that (a) for the values of EVI denoting vegetated land cover $(>0.2)$ the mean $\mathrm{NO}_{2}$ levels are low $\left(<1 \times 10^{15} \mathrm{molec} \mathrm{cm}^{-2}\right)$ and (b) the increase of the EVI is accompanied by a further decrease of the $\mathrm{NO}_{2}$ level. This is consistent with the anti-correlation observed for the $R_{\mathrm{GF}}$ and $\mathrm{VCD}_{\mathrm{NO}_{2}}$ (Fig. 6c). 
Table 3. Computed vertical column densities of $\mathrm{NO}_{2}$ and $R_{\mathrm{GF}}$ ratio for a selection of cities/areas along with their corresponding latitude $(\mathrm{N}>0, \mathrm{~S}<0)$, longitude $(\mathrm{E}>0, \mathrm{~W}<0)$ and population records. The $\mathrm{VCD}_{\mathrm{NO}_{2}}$ and $R_{\mathrm{GF}}$ corresponds to a box region of dimensions $0.25 \times 0.25^{\circ}$ surrounding a central point denoted by the given coordinates.

\begin{tabular}{llccccc}
\hline \multirow{2}{*}{ City/Area } & Location & \multicolumn{2}{c}{ Coordinates } & Population* & $\mathrm{VCD}_{\mathrm{NO}_{2}}$ & $R_{\mathrm{GF}}$ \\
\cline { 3 - 4 } & & LAT & LON & {$\left[\times 10^{6}\right]$} & {$\left[10^{16} \mathrm{molec}^{-2}\right]$} & ratio \\
\hline Istanbul & Eurasia & 41.0 & 29.0 & 12.50 & 1.43 & 0.037 \\
Lisbon & Eurasia & 38.9 & -9.1 & 2.82 & 0.05 & 0.054 \\
Paris & Eurasia & 48.8 & 2.5 & 10.00 & 1.37 & 0.041 \\
Po Valley & Eurasia & 45.0 & 10.5 & 6.00 & 1.50 & 0.027 \\
Rome & Eurasia & 41.9 & 12.6 & 2.72 & 0.77 & 0.044 \\
Ruhr area & Eurasia & 51.5 & 6.5 & 5.70 & 1.73 & 0.034 \\
Johannesburg & Africa & -26.2 & 28.0 & 7.35 & 0.91 & 0.046 \\
Delhi & Southern Asia & 28.6 & 77.2 & 22.40 & 0.77 & 0.040 \\
Beijing & Eastern Asia & 40.0 & 116.4 & 13.20 & 2.51 & 0.031 \\
Hong Kong & Eastern Asia & 22.3 & 114.0 & 6.86 & 2.15 & 0.039 \\
Shanghai & Eastern Asia & 31.3 & 121.3 & 17.90 & 3.34 & 0.031 \\
Seoul & Eastern Asia & 37.5 & 127.0 & 23.90 & 2.81 & 0.033 \\
Tianjin & Eastern Asia & 39.0 & 117.7 & 8.20 & 3.67 & 0.024 \\
Tokyo & Eastern Asia & 35.8 & 139.6 & 33.80 & 1.70 & 0.037 \\
Manila & Southeast Asia & 14.6 & 121.0 & 19.20 & 0.40 & 0.051 \\
Jakarta & Southeast Asia & -6.3 & 106.9 & 15.10 & 0.72 & 0.042 \\
Kuala Lumpur & Southeast Asia & 3.1 & 101.7 & 4.70 & 0.48 & 0.041 \\
Melbourne & Australia & -37.9 & 145.0 & 3.90 & 0.40 & 0.043 \\
Sydney & Australia & -33.9 & 151.2 & 4.40 & 0.35 & 0.043 \\
Los Angeles & North America & 34.1 & -117.8 & 18.00 & 1.83 & 0.041 \\
New York & North America & 40.7 & -74.0 & 21.90 & 2.46 & 0.030 \\
\hline & & & & & & \\
\hline
\end{tabular}

* Source of the population figures of the selected agglomerations: http://www.citypopulation.de/

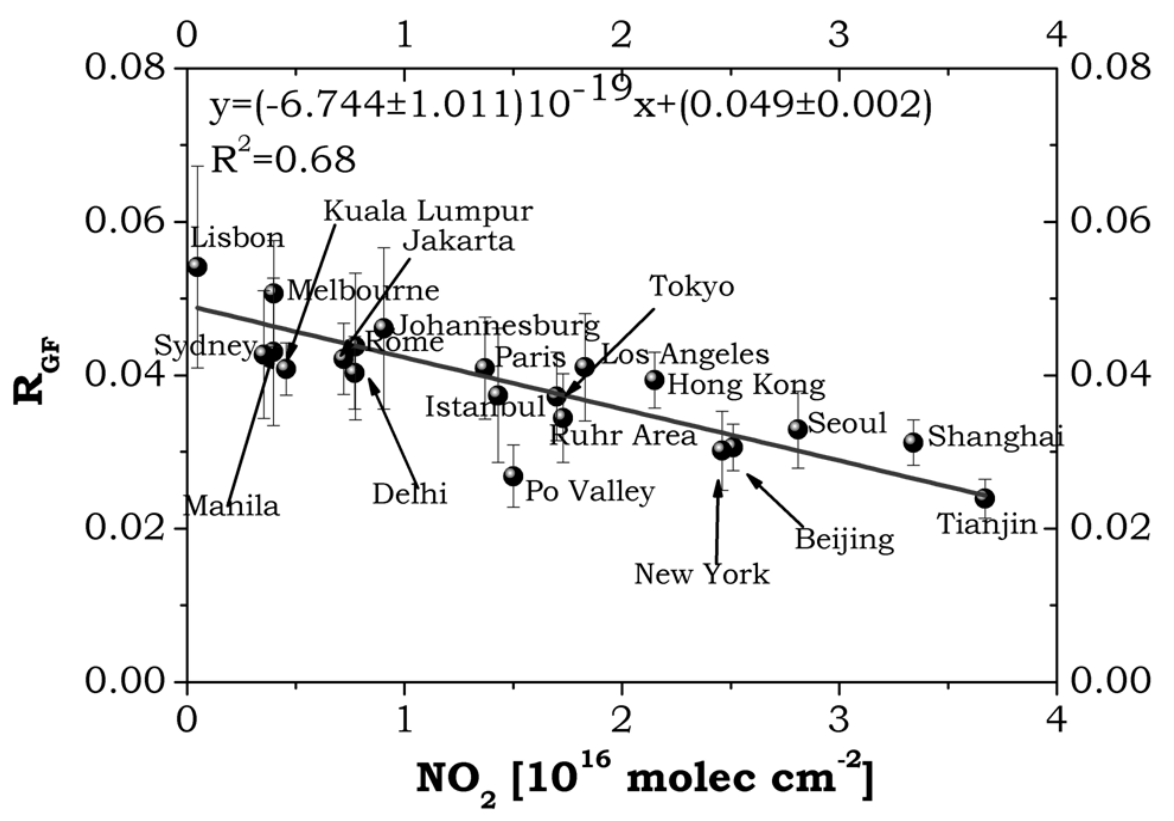

Fig. 7. Mean $R_{\mathrm{GF}}$ ratio, as a function of the $\mathrm{VCD}_{\mathrm{NO}_{2}}$ amounts, over 21 cities/areas and for the period 2007-2008. Cities with high $\mathrm{NO} 2$ levels experience lower $R_{\mathrm{GF}}$ values while cities with low $\mathrm{NO}_{2}$ levels show higher $R_{\mathrm{GF}}$ ratios. 


\subsection{Implications: $\boldsymbol{R}_{\mathrm{GF}}$ ratio over cities}

$R_{\mathrm{GF}}$ decreases when the $\mathrm{NO}_{2}$ column amounts increase. In order to test the validity of this finding, the $R_{\mathrm{GF}}$ ratio based on the GOME-2 $\mathrm{VCD}_{\mathrm{CHO}}$.CHO and $\mathrm{VCD}_{\mathrm{HCHO}}$ values has been computed over 21 cities/areas (Table 3 ) which are characterized by various $\mathrm{NO}_{2}$ levels. The mean vertical column density of each trace gas was computed for the squared area with dimensions equal to $0.25^{\circ} \times 0.25^{\circ}$ with the central location denoted by the coordinates listed in Table 1, for the total period 2007-2008. The graphic representation of the results (Fig. 7) verifies that the most polluted cities/areas (New York, Beijing, Seoul, Shanghai, Tianjin), in terms of $\mathrm{NO}_{2}$ levels, experience low $R_{\mathrm{GF}}$ values $(\leq 0.032)$ while cities with relatively low $\mathrm{NO}_{2}$ levels (e.g. Lisbon, Melbourne, Sydney) are characterized by $R_{\mathrm{GF}}$ values greater than 0.040 . This can be explained by the large amounts of $\mathrm{NO}_{2}$ associated with anthropogenic emissions of fossil fuel VOC and CO. In the city regions, $\mathrm{O}_{3}$ is often titrated by the large amounts of $\mathrm{NO}$ present. The oxidation rate of VOC then increases downwind of the city. The value of $R_{\mathrm{GF}}$ is attributed to the type of hydrocarbon (e.g. aromatics) or fuel mix present.

The compact correlation found for a large range of different cities is surprising as one might have expected different behaviour for cities such as New York and Beijing which have different emission patterns for both VOC and NOx. Also the absolute values of $\mathrm{HCHO}$ and $\mathrm{CHO} . \mathrm{CHO}$ were shown to correlate only weakly with $\mathrm{NO}_{2}$. The close link between the ratio $R_{\mathrm{GF}}$ and $\mathrm{NO}_{2}$ indicates that either the anthropogenic emissions of $\mathrm{HCHO}$ are proportional to those of $\mathrm{NO}_{\mathrm{x}}$ or that at high $\mathrm{NO}_{\mathrm{x}}$ levels the $\mathrm{HCHO}$ yield is higher than that of glyoxal.

It would be interesting to check if current atmospheric models having enough spatial resolution are able to reproduce the correlation between $\mathrm{NO}_{2}$ and $R_{\mathrm{GF}}$ observed in the data and to investigate if this ratio can also provide information on the ozone formation potential in the different cities.

\section{Conclusions}

This study presents the first GOME-2 observations of HCHO and CHO.CHO on a global scale. The annual composite maps of both species indicate the existence of high column amounts over the tropical regions, over biomass burning regions and over urban areas. This close match of the global pattern of both species confirms their common biogenic, anthropogenic and biomass burning sources. The comparison of the land values used for this study with the ones retrieved from SCIAMACHY measurements shows excellent agreement with only a few percent of underestimation and overestimation with the GOME-2 CHO.CHO and HCHO, respectively.

A detailed analysis of these OVOC species with the synergistic use of $\mathrm{NO}_{2}$ columns and EVI was performed in order to investigate the connection of the ratio between $\mathrm{CHO}$.CHO and $\mathrm{HCHO}, R_{\mathrm{GF}}$, and the anthropogenic and biogenic emissions. It was found that for vegetated land cover, the $R_{\mathrm{GF}}$ varies from 0.04 to 0.06 with the highest values being computed for regions covered by very dense vegetation (e.g. tropical rain forests). This indicates that biogenic precursors favor CHO.CHO production. In contrast to these regions with very small $\mathrm{NO}_{2}$ vertical column densities, areas with enhanced $\mathrm{NO}_{2}$ levels show smaller $R_{\mathrm{GF}}$ which can drop below the limit of 0.030 for highly polluted conditions. This is interpreted as indication for higher $\mathrm{HCHO}$ production from anthropogenic precursors or for additional primary $\mathrm{HCHO}$ sources. To crosscheck the validity of these conclusions, the mean $R_{\mathrm{GF}}$ values were computed for 21 cities/areas from different parts of the globe. It was found that regardless of geographical region, the more polluted cities of the study experience lower $R_{\mathrm{GF}}$ values in comparison to the less polluted ones. This is attributed to the larger emissions of anthropogenic VOC in such air masses.

A challenge for current atmospheric models will be to reproduce the observed trends in $\mathrm{CHO}$.CHO, $\mathrm{HCHO}$ and in particular their ratio $R_{\mathrm{GF}}$ for different source types. As the absolute values of the ratios are sensitive to the accuracy of the columns, further validation of the satellite data with independent measurements is needed at different times and latitudes to better constrain the accuracy of the results.

Acknowledgements. Mihalis Vrekoussis acknowledges the A. von Humboldt foundation and the European Union (Marie Curie) for the consecutive research fellowships. We appreciate the provision of MODIS data via the internet by NASA/GSFC. This work has in part been funded by the DLR, the State of Bremen, and the EU ACCENT Project. The UB thanks the ESA and DLR for the provision of level 0 and level 1 data from SCIAMACHY and EUMETSAT for the GOME-2 level 1 data. This study has been supported by the EC FP7 project CityZen (grant no. 212095) and contributed to the EC FP7 ACCENT and ACCENT PLUS projects.

Edited by: B. N. Duncan

\section{References}

Anderson, L. G., Lanning, J. A., Barrell, R., Miyagishima, J., Jones, R. H., and Wolfe, P: Sources and sinks of formaldehyde and acetaldehyde: an analysis of Denver's ambient concentration data, Atmos. Environ., 30, 12, 2113-2123, 1996.

Andreae, M. O. and Merlet, P.: Emission of Trace Gases and Aerosols from Biomass Burning, Global Biogeochem. Cy., 15, 955-966, doi:10.1029/2000GB001382, 2000.

Arlander, D. W., Bruning, D., Schmidt, U., and Ehhalt, D. H: The Tropospheric Distribution of Formaldehyde during Tropoz-Ii, J. Atmos. Chem., 22, 3, 251-269, 1995.

Barkley, M. P., Palmer, P. I., De Smedt, I., Karl, T., Guenther, A., and Van Roozendael, M.: Regulated large-scale annual shutdown of Amazonian isoprene emissions?, Geophys. Res. Lett., 36, L04803, doi:10.1029/2008GL036843, 2009. 
Burrows, J. P., Weber, M., Buchwitz, M., Rozanov, V. V., Ladstätter-Weißenmayer, A., Richter, A., de Beek, R., Hoogen, R., Bramstedt, K., Eichmann, K.-U., Eisinger M., and Perner, D.: The Global Ozone Monitoring Experiment (GOME): Mission Concept and First Scientific Results, J. Atmos. Sci., 56, 151-175, 1999.

Callies, J., Corpaccioli, E., Eisinger, M., Hahne, A., and Lefebvre, A.: GOME-2 metops second-generation sensor for operational ozone monitoring, ESA bulletin, 102, 28-36, 2000.

Calvert, J. G., Atkinson, R., Becker, K. H., Kamens, R. M., Seinfeld, J. H., Wallington, T. J., and Yarwood, G: The Mechanisms of Atmospheric Oxidation of Aromatic Hydrocarbons, Oxford University Press, Oxford, 566 pp., 2002.

Carrão, H., Gonçalves, P., and Caetano, M.: Contribution of multispectral and multitemporal information from MODIS images to land cover classification, Remote Sens. Environ., 112 (3), 986997, 2007.

De Smedt, I., Mller, J.-F., Stavrakou, T., van der A, R., Eskes, H., and Van Roozendael, M.: Twelve years of global observations of formaldehyde in the troposphere using GOME and SCIAMACHY sensors, Atmos. Chem. Phys., 8, 4947-4963, doi:10.5194/acp-8-4947-2008, 2008.

Dufour, G., Wittrock, F., Camredon, M., Beekmann, M., Richter, A., Aumont, B., and Burrows, J. P.: SCIAMACHY formaldehyde observations: constraint for isoprene emission estimates over Europe?, Atmos. Chem. Phys., 9, 1647-1664, doi:10.5194/acp-9-1647-2009, 2009.

Fleischmann, O. C., Hartmann, M., Burrows, J. P., and Orphal, J.: New ultraviolet absorption crosssections of $\mathrm{BrO}$ at atmospheric temperatures measured by time-windowing Fourier transform spectroscopy, J. Photoch Photobio A, 168 (1-2), 117-132, 2004.

Fried, A., Crawford, J., Olson, J., Walega, J., Potter, W., Wert, B., Jordan, C., Anderson, B., Shetter, R., Lefer,B., Blake, D., Blake, N., Meinardi, S., Heikes, B., O’Sullivan, D., Snow, J., Fuelberg, H., Kiley, C. M., Sandholm, S., Tan, D., Sachse, G., Singh, H., Faloona, I., Harward, C. N. and Carmichael, G.R.: Airborne tunable diode laser measurements of formaldehyde during TRACEP: Distributions and box model comparisons. J. Geophys. Res.Atmos., 108 (D20), 8798, doi:10.1029/2003JD003451, 2003.

Frost, G. J., Fried, A., Lee, Y.-N., Wert, B., Henry, B., Drummond, J. R., Evans, M. J., Fehsenfeld, F. C., Goldan, P. D., Holloway, J. S., Huebler, G., Jakoubek, R., Jobson, B. T., Knapp, K., Kuster, W. C., Roberts, W. C., Rudolph, J., Ryerson, T. B., Stohl, A., Stroud, C., Sueper, D. T., Trainer, M., and Williams, J.: Comparisons of box model calculations and measurements of formaldehyde from the 1997 North Atlantic Regional Experiment, J. Geophys. Res., 107 (D8), 4060, doi:10.1029/2001JD000896, 2002.

Fu, T.-M., Jacob, D. J., Palmer, P. I., Chance, K., Wang, Y. X., Barletta, B., Blake, D. R., Stanton, J. C., and Pilling, M. J.: Space-based formaldehyde measurements as constraints on volatile organic compound emissions in east and south Asia and implications for ozone, J. Geophys. Res., 112, D06312, doi:10.29/2006JG007853, 2007.

Fu, T. M., Jacob, D. J., Wittrock, F., Burrows, J. P., Vrekoussis, M., and Henze, D. K.: Global budgets of atmospheric glyoxal and methylglyoxal, and implications for formation of secondary organic aerosols, J. Geophys. Res., 113, D15303, doi:10.1029/2007jd009505, 2008.

Fu, T.-M., Jacob, D. J., and Heald, C. L: Aqueous-phase reactive uptake of dicarbonyls as a source of organic aerosol over eastern North America, Atmos. Environ., 43(10), 1814-1822, 2009.

Geiger, H., Kleffmann, J., and Wiesen, P.: Smog chamber studies on the influence of diesel exhaust on photosmog formation, Atmos. Environ., 36 (11), 1737-1747, 2002.

Gottwald, M., Bovensmann, H., Lichtenberg, G., Noel, S., von Bargen, A., Slijkhuis, S., Piters, A., Hoogeveen, R., von Savigny, C., Buchwitz, M., Kokhanovsky, A., Richter, A., Rozanov, A., Holzer-Popp, T., Bramstedt, K., Lambert, J.-C., Skupin, J., Wittrock, F., Schrijver, H., and Burrows, J. P.: SCIAMACHY, Monitoring the Changing Earth's Atmosphere, Published by DLR, 2006.

Greenblatt, G. D., Orlando, J. J., Burkholder, J. B., and Ravishankara, A. R.: Absorption-Measurements of Oxygen between 330nm and 1140nm, J. Geophys. Res.-Atmos., 95, 18577$18582,1990$.

Grosjean, D., Grosjean, E., and Gertler, A. W.: On-road emissions of carbonyls from light-duty and heavy-duty vehicles, Environ. Sci. Technol., 35, 45-53, 2001.

Guenther, A., Karl, T., Harley, P., Wiedinmyer, C., Palmer, P. I., and Geron, C.: Estimates of global terrestrial isoprene emissions using MEGAN (Model of Emissions of Gases and Aerosols from Nature), Atmos. Chem. Phys., 6, 3181-3210, doi:10.5194/acp-63181-2006, 2006.

Gür, B., Spietz, P., Orphal, J., and Burrows, J.: Absorption Spectra Measurements with the GOME-2 FMs using the IUP/IFE-UB's Calibration Apparatus for Trace Gas Absorption Spectroscopy CATGAS, Final Report, IUP University of Bremen, Oct, 2005.

Hassan, Q. K. and Bourque, C. P.: Spatial Enhancement of MODISbased Images of Leaf Area Index: Application to the Boreal Forest Region of Northern Alberta, Canada Remote Sensing, 2, 278289, 2010.

Hays, M. D., Geron, C. D., Linna, K. J., Smith, N. D., and Schauer, J. J.: Speciation of gas-phase and fine particle emissions from burning of foliar fuels, Environ. Sci. Technol., 36, 2281-2295, doi:10.1021/Es0111683, 2002.

Heikes, B., Snow, J., Egli, P., O’Sullivan, D., Crawford, J., Olson, J., Chen, G., Davis, D., Blake, N., and Blake, D.: Formaldehyde over the central Pacific during PEM-Tropics B, J. Geophys. Res., 106(D23), 32717-32731, 2001.

Hild, L., Richter, A., Rozanov, V., and Burrows, J. P: Air mass factorcalculations for GOME measurements of lightning-produced $\mathrm{NO}_{2}$, Adv. Space Res., 29(11), 1685-1690, 2002.

Holzinger, R., Warneke, C., Hansel, A., Jordan, A., Lindinger, W., Scharffe, D. H., Schade, G., and Crutzen, P. J.: Biomass burning as a source of formaldehyde, acetaldehyde, methanol, acetone, acetonitrile and hydrogen cyanide, Geophys. Res. Lett., 26(8), 1161-1164, 1999.

Houweling, S., Dentener, F., and Lelieveld, J.: The impact of nonmethane hydrocarbon compounds on tropospheric photochemistry, J. Geophys. Res.-Atmos., 103, 10673-10696, 1998.

Huete, A., Didan, K., Miura, T., Rodriguez, E. P., Gao, X., and Ferreira, L. G.: Overview of the radiometric and biophysical performance of the MODIS vegetation indices, Remote Sens. Environ., 83, 195-213, 2002.

Justice, C. O., Vermote, E., Townshend, J. R. G., Defries, R., Roy, D. P., Hall, D. K., Salomonson, V. V., Privette, J. L., Riggs, G., Strahler, A., Lucht, W., Myneni, R. B., Knyazikhin, Y., Running, S. W., Nemani, R. R., Zhengming Wan, Huete, A. R., 
van Leeuwen, W., Wolfe, R. E., Giglio, L., Muller, J., Lewis, P., and Barnsley, M. J: The Moderate Resolution Imaging Spectroradiometer (MODIS): Land remote sensing for global change research, Geosci. Remote Sens., IEEE Transactions, 36, Issue 4, July 1998 1228-1249, 1998.

Kanakidou, M., Seinfeld, J. H., Pandis, S. N., Barnes, I., Dentener, F. J., Facchini, M. C., Van Dingenen, R., Ervens, B., Nenes, A., Nielsen, C. J., Swietlicki, E., Putaud, J. P., Balkanski, Y., Fuzzi, S., Horth, J., Moortgat, G. K., Winterhalter, R., Myhre, C. E. L., Tsigaridis, K., Vignati, E., Stephanou, E. G., and Wilson, J.: Organic aerosol and global climate modelling: a review, Atmos. Chem. Phys., 5, 1053-1123, doi:10.5194/acp-5-1053-2005, 2005

Kean, A. J., Grosjean, E., Grosjean, D., and Harley, R. A: On-road measurement of carbonyls in California light-duty vehicle emissions, Environ. Sci. Technol., 35, 4198-4204, 2001.

Kroll, J. H., Ng, N. L., Murphy, S. M., Varutbangkul, V., Flagan, R. C., and Seinfeld, J. H.: Chamber studies of secondary organic aerosol growth by reactive uptake of simple carbonyl compounds, J. Geophys. Res.-Atmos., 110, D23207, doi:10.1029/2005jd006004, 2005.

Kwan, A. J., Crounse, J. D., Clarke, A. D., Shinozuka, Y., Anderson, B. E., Crawford, J. H., Avery, M. A., McNaughton, C. S., Brune, W. H., Singh, H. B., and Wennberg, P. O.: On the flux of oxygenated volatile organic compounds from organic aerosol oxidation, Geophys. Res. Lett., 33, L15815, doi:10.1029/2006GL026144, 2006.

Lee, Y. N., Zhou, X. L., and Hallock, K.: Atmospheric carbonyl compounds at a rural southeastern United States site, J. Geophys. Res.-Atmos., 100, 25933-25944, 1995.

Lee, D. S., Köhler, I., Grobler, E., Rohrer, F., Sausen, R., GallardoKlenner, L., Olivier, J. H. J., Dentener, F. J., and Bouwman, A. F.: Estimations of global $\mathrm{NO}_{\mathrm{x}}$ emissions and their uncertainties, Atmos. Environ., 31, 1735-1749, 1997.

Lee, M., Heikes, B. G., Jacob, D. J., Sachse, G., and Anderson, B.: Hydrogen peroxide, organic peroxides, and formaldehyde as primary pollutants from biomass burning, J. Geophys. Res., 102, 1301-1309, 1997.

Liakakou, E., Vrekoussis, M., Bonsang, B., Donousis, C., Kanakidou, M., and Mihalopoulos, N.: Isoprene above the Eastern Mediterranean: Seasonal variation and contribution to the oxidation capacity of the atmosphere, Atmos. Environ., 41(5), 10021010, 2007.

Liggio, J., Li, S. M., and McLaren, R.: Reactive uptake of glyoxal by particulate matter, J. Geophys. Res., 110, D10304, doi:10310.11029/2004JD005113, 2005.

Lowe, D. C. and Schmidt, U.: Formaldehyde (HCHO) measurementsin the nonurban atmosphere, J. Geophys. Res., 88(15), 844-858, 1983

Marbach, T., Beirle, S., Platt, U., Hoor, P., Wittrock, F., Richter, A., Vrekoussis, M., Grzegorski, M., Burrows, J. P., and Wagner, T.: Satellite measurements of formaldehyde linked to shipping emissions, Atmos. Chem. Phys., 9, 8223-8234, doi:10.5194/acp9-8223-2009, 2009.

Martin, R. V., Sioris, C. E., Chance, K., Ryerson, T. B., Bertram, T. H., Wooldridge, P. J., Cohen, R. C., Neuman, J. A., Swanson, A., and Flocke, F. M.: Evaluation of space-based constraints on global nitrogen oxide emissions with regional aircraft measurements over and downwind of eastern North America, J. Geophys.
Res., 111, D15308, doi:10.1029/2005JD006680, 2006.

Meller, R. and Moortgat, G. K.: Temperature dependence of the absorption cross sections of formaldehyde between 223 and $323 \mathrm{~K}$ in the wavelength range $225-375 \mathrm{~nm}$, J. Geophys. Res.-Atmos., 105 (D6), 7089-7101, 2000.

Millet, D. B., Jacob, D. J., Turquety, S., Hudman, R. C., Wu, S., Fried, A., Walega, J., Heikes, B. G., Blake, D. R., Singh, H. B., Anderson, B. E., and Clarke, A. D.: Formaldehyde distribution over North America: Implications for satellite retrievals of formaldehyde columns and isoprene emission, J. Geophys. Res., 111, D24S02, doi:10.1029/2005JD006853, 2006.

Monks, P. S: Gas-phase radical chemistry in the troposphere, Chem. Soc. Rev., 34, 376-395, doi:10.1039/B307982c, 2005.

Munger, J. W., Jacob, D. J., Daube, B. C., Horowitz, L. W., Keene, W. C., and Heikes, B. G.: Formaldehyde, Glyoxal, and Methylglyoxal in Air and Cloudwater at a Rural Mountain Site in Central Virginia, J. Geophys. Res.-Atmos., 100, 9325-9333, 1995.

Myriokefalitakis, S., Vrekoussis, M., Tsigaridis, K., Wittrock, F., Richter, A., Brhl, C., Volkamer, R., Burrows, J. P., and Kanakidou, M.: The influence of natural and anthropogenic secondary sources on the glyoxal global distribution, Atmos. Chem. Phys., 8, 4965-4981, doi:10.5194/acp-8-4965-2008, 2008.

Palmer, P. I., Jacob, D. J., Fiore, A. M., Martin, R. V., Chance, K., and Kurosu, T. P.: Mapping isoprene emissions over North America using formaldehyde column observations from space, J. Geophys. Res.-Atmos., 108(D6), 4180, doi:10.1029/2002jd002153, 2003.

Palmer, P. I., Abbot, D. S., Fu, T. M., Jacob, D. J., Chance, K., Kurosu, T. P., Guenther, A., Wiedinmyer, C., Stanton, J. C., Pilling, M. J., Pressley, S. N., Lamb, B., and Sumner, A. L: Quantifying the seasonal and interannual variability of North American isoprene emissions using satellite observations of the formaldehyde column, J. Geophys. Res.-Atmos., 111, D12315, doi:10.1029/2005jd006689, 2006.

Platt, U.: Differential optical absorption spectroscopy (DOAS): Air Monitoring by Spectroscopic Techniques, edited by: Sigrist, M. W., John Wiley \& Sons, Inc., New York, 127, 27-84, 1994.

Poisson, N., Kanakidou, M., and Crutzen, P. J.: Impact of nonmethane hydrocarbons on tropospheric chemistry and the oxidizing power of the global troposphere: 3-dimensional modelling results, J. Atmos. Chem., 36, 157-230, 2000.

Pope, R. M., and Fry, E. S.: Absorption spectrum (380-700 nm) of pure water. II. Integrating cavity measurements, Appl. Optics, 36, 8710-8723, 1997.

Richter, A. and Burrows, J. P.: Tropospheric $\mathrm{NO}_{2}$ from GOME Measurements, Adv. Space Res., 29(11), 1673-1683, 2001.

Richter, A., Burrows, J. P., Nuss, H., Granier, C., and Niemeier, U: Increase in tropospheric nitrogen dioxide over China observed from space, Nature, 437, 129-132, doi:10.1038/Nature04092, 2005.

Roberts, G. C., Artaxo, P., Zhou, J. C., Swietlicki, E., and Andreae, M. O: Sensitivity of CCN spectra on chemical and physical properties of aerosol: A case study from the Amazon Basin, J. Geophys. Res.-Atmos., 107(D20), 8070, doi:10.1029/2001jd000583, 2002.

Rothman, L. S., Gamache, R. R., Tipping, R. H., Rinsland, C. P., Smith, M. A. H., Benner, C. D., Devi, V. M., Flaud, J. M., CamyPeyret, C., Perrin, A., Goldman, A., Massie, S. T., and Brown, L. R.: The HITRAN molecular database editions 1991 and 1992, J. 
Quant. Spectrosc. Ra., 48, 469-507, HITRAN, $\mathrm{H}_{2} \mathrm{O}$, laboratory, 1992.

Rozanov, A., Rozanov, V., Buchwitz, M., Kokhanovsky, A., and Burrows, J. P.: SCIATRAN 2.0 - A new radiative transfer model for geophysical applications in the $175-2400 \mathrm{~nm}$ spectral region, Atmos. Remote Sensing: Earth's Surface, Troposphere, Stratosphere and Mesosphere-I, 36, 1015-1019, doi:10.1016/j.asr.2005.03.012, 2005.

Sayer, A. M., Thomas, G. E., Grainger, R. G., Carboni E., Poulsen, C., Siddans, R., Richter, A., Vrekoussis, M., and Wittrock, F.: Biomass burning in the Amazon: Links between burning, trace gases, and aerosol and surface properties from the ORACAATSR retrieval, submitted, Remote Sens. Environ., 2010.

Seco, R., Penuelas, J., and Filella, I.: Short-chain oxygenated VOCs: Emission and uptake by plants and atmospheric sources, sinks, and concentrations, Atmos. Environ., 41, 2477-2499, 2007.

Singh, H., Chen, Y., Staudt, A., Jacob, J., Blake, D., Heikes, B., and Snow, J.: Evidence from the Pacific troposphere for large global sources of oxygenated organic compounds, Nature, 410, 2001.

Singh, H. B., Salas, L. J., Chatfield, R. B., Czech, E., Fried, A., Walega, J., Evans, M. J., Field, B. D., Jacob, D. J., Blake, D., Heikes, B., Talbot, R., Sachse, G., Crawford, J. H., Avery, M. A., Sandholm, S., and Fuelberg, H.: Analysis of the atmospheric distribution, sources, and sinks of oxygenated volatile organic chemicals based on measurements over the Pacific during TRACE-P, J. Geophys. Res.-Atmos., 109 (D15), 2004.

Spaulding, R. S., Schade, G. W., Goldstein, A. H., and Charles, M. J.: Characterization of secondary atmospheric photooxidation products: Evidence for biogenic and anthropogenic sources, J. Geophys. Res. Atmos., 108(D8), 4247, doi:10.1029/2002jd002478, 2003.

Stavrakou, T., Müller, J.-F., De Smedt, I., Van Roozendael, M., van der Werf, G. R., Giglio, L., and Guenther, A.: Evaluating the performance of pyrogenic and biogenic emission inventories against one decade of space-based formaldehyde columns, Atmos. Chem. Phys., 9, 1037-1060, doi:10.5194/acp-9-1037-2009, 2009a.

Stavrakou, T., Mller, J.-F., De Smedt, I., Van Roozendael, M., Kanakidou, M., Vrekoussis, M., Wittrock, F., Richter, A., and Burrows, J. P.: The continental source of glyoxal estimated by the synergistic use of spaceborne measurements and inverse modelling, Atmos. Chem. Phys., 9, 8431-8446, doi:10.5194/acp-9-8431-2009, 2009b.

Vigouroux, C., Hendrick, F., Stavrakou, T., Dils, B., De Smedt, I., Hermans, C., Merlaud, A., Scolas, F., Senten, C., Vanhaelewyn, G., Fally, S., Carleer, M., Metzger, J.-M., Müller, J.-F., Van Roozendael, M., and De Mazière, M.: Ground-based FTIR and MAX-DOAS observations of formaldehyde at Réunion Island and comparisons with satellite and model data, Atmos. Chem. Phys., 9, 9523-9544, doi:10.5194/acp-9-9523-2009, 2009.

Volkamer, R., Spietz, P., Burrows, J., and Platt, U: High-resolution absorption cross-section of glyoxal in the UV-vis and IR spectral ranges, J. Photochem. Photobio. A, 172, 35-46, 2005a.
Volkamer, R., Molina, L. T., Molina, M. J., Shirley, T., and Brune, W. H.: DOAS measurement of glyoxal as an indicator for fast VOC chemistry in urban air, Geophys. Res. Lett., 32, L08806, doi:10.1029/2005g1022616, 2005b.

Volkamer, R., Jimenez, J. L., San Martini, F., Dzepina, K., Zhang, Q., Salcedo, D., Molina, L. T., Worsnop, D. R., and Molina, M. J.: Secondary organic aerosol formation from anthropogenic air pollution: Rapid and higher than expected, Geophys. Res. Lett., 33, L17811, doi:10.1029/2006g1026899, 2006.

Volkamer, R., Martini, F. S., Molina, L. T., Salcedo, D., Jimenez, J. L., and Molina, M. J.: A missing sink for gas-phase glyoxal in Mexico City: Formation of secondary organic aerosol, Geophys. Res. Lett., 34, L19807, doi:10.1029/2007g1030752, 2007.

Vountas, M., Rozanov, V. V., and Burrows, J. P.: Ring effect: Impact of rotational Raman scattering on radiative transfer in earth's atmosphere. J. Quant. Spectrosc. Ra., 60, 943-961, 1998.

Vrekoussis, M., Kanakidou, M., Mihalopoulos, N., Crutzen, P. J., Lelieveld, J., Perner, D., Berresheim, H., and Baboukas, E.: Role of the $\mathrm{NO}_{3}$ radicals in oxidation processes in the eastern Mediterranean troposphere during the MINOS campaign, Atmos. Chem. Phys., 4, 169-182, doi:10.5194/acp-4-169-2004, 2004.

Vrekoussis, M., Liakakou, E., Mihalopoulos, N., Kanakidou, M., Crutzen, P. J., and Lelieveld, J.: Formation of $\mathrm{HNO}_{3}$ and $\mathrm{NO}_{3}^{-}$in the anthropogenically-influenced eastern Mediterranean marine boundary layer, Geophys. Res. Lett., 33, L05811, doi:10.1029/2005GL025069, 2006.

Vrekoussis, M., Mihalopoulos, N., Gerasopoulos, E., Kanakidou, M., Crutzen, P. J., and Lelieveld, J.: Two-years of $\mathrm{NO}_{3}$ radical observations in the boundary layer over the Eastern Mediterranean, Atmos. Chem. Phys., 7, 315-327, doi:10.5194/acp-7315-2007, 2007.

Vrekoussis, M., Wittrock, F., Richter, A., and Burrows, J. P.: Temporal and spatial variability of glyoxal as observed from space, Atmos. Chem. Phys., 9, 4485-4504, doi:10.5194/acp-9-44852009, 2009.

Weller, R., Schrems, O., Boddenberg, A., Gäb, S., and Gautrois, M.: Meridional distribution of hydroperoxides and formaldehyde in the marine boundary layer of the Atlantic $\left(48^{\circ} \mathrm{N}-35 ?^{\circ} \mathrm{S}\right)$ measured during the Albatross campaign, J. Geophys. Res., 105(D11), 14401-14412, 2000.

Williams, J.: Organic trace gases in the atmosphere, an overview, Environ. Chem., 2004, 1, 125-136, doi:10.1071/EN04057, 2004.

Wittrock, F., Richter, A., Oetjen, H., Burrows, J. P., Kanakidou, M., Myriokefalitakis, S., Volkamer, R., Beirle, S., Platt, U., and Wagner, T.: Simultaneous global observations of glyoxal and formaldehyde from space, Geophys. Res. Lett., 33, L16804, doi:10.1029/2006g1026310, 2006.

Wittrock, F.: The Retrieval of oxygenated volatile organic compounds by remote sensing techniques, $\mathrm{PhD}$ thesis, Bremen University, 2006.

Yokelson, R. J., Goode, J. G., Ward, D. E., Susott, R. A., Babbitt, R. E., Wade, D. D., Bertschi, I., Griffith, D. W. T., and Hao, W. M: Emissions of formaldehyde, acetic acid, methanol, and other trace gases from biomass fires in North Carolina measured by airborne Fourier transform infrared spectroscopy, J. Geophys. Res.-Atmos., 104 (D23), 30109-30125, 1999. 